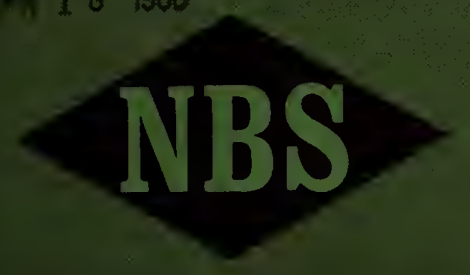

\title{
Spectral Emission Properties of NBS Standard Phosphor Samples Under Photo-Excitation
}

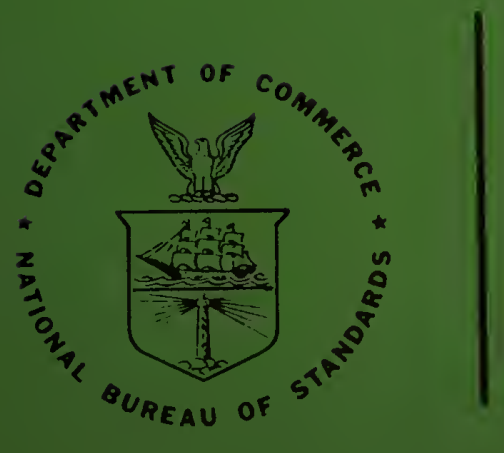

U.S. DEPARTMENT OF COMMERCE National Bureau of Standards 


\section{THE NATIONAL BUREAU OF STANDARDS}

The National Bureau of Standards ${ }^{1}$ provides measurement and technical information services essential to the efficiency and effectiveness of the work of the Nation's scientists and engineers. The Bureau serves also as a focal point in the Federal Government for assuring maximum application of the physical and engineering sciences to the advancement of technology in industry and commerce. To accomplish this mission, the Bureau is organized into three institutes covering broad program areas of research and services:

THE INSTITUTE FOR BASIC STANDARDS .... provides the central basis within the United States for a complete and consistent system of physical measurements, coordinates that system with the measurement systems of other nations, and furnishes essential services leading to accurate and uniform physical measurements throughout the Nation's scientific community, industry, and commerce. This Institute comprises a series of divisions, each serving a classical subject matter area:

-Applied Mathematics-Electricity-Metrology-Mechanics-Heat-Atomic Physics-Physical Chemistry-Radiation Physics--Laboratory Astrophysics ${ }^{2}$-Radio Standards Laboratory, ${ }^{2}$ which includes Radio Standards Physics and Radio Standards Engineering-Office of Standard Reference Data.

THE INSTITUTE FOR MATERIALS RESEARCH . . . conducts materials research and provides associated materials services including mainly reference materials and data on the properties of materials. Beyond its direct interest to the Nation's scientists and engineers, this Institute yields services which are essential to the advancement of technology in industry and commerce. This Institute is organized primarily by technical fields:

-Analytical Chemistry-Metallurgy-Reactor Radiations-Polymers-Inorganic Materials-Cryogenics ${ }^{2}$-Office of Standard Reference Materials.

THE INSTITUTE FOR APPLIED TECHNOLOGY . . . provides technical services to promote the use of available technology and to facilitate technological innovation in industry and government. The principal elements of this Institute are:

-Building Research-Electronic Instrumentation-Technical Analysis-Center for Computer Sciences and Technology-Textile and Apparel Technology Center-Office of Weights and Measures -Office of Engineering Standards Services-Office of Invention and Innovation-Office of Vehicle Systems Research-Clearinghouse for Federal Scientific and Technical Information ${ }^{3}$-Materials Evaluation Laboratory-NBS/GSA Testing Laboratory.

'Headquarters and Laboratories at Gaithersburg, Maryland, unless otherwise noted; mailing address Washington, D. C., 20234.

${ }^{2}$ Located at Boulder, Colorado, 80302.

${ }^{3}$ Located at 5285 Port Royal Road, Springfield, Virginia 22151. 
UNITED STATES DEPARTMENT OF COMMERCE

C. R. Smith, Secretary

NATIONAL BUREAU OF STANDARDS - A. V. Astin, Director

\title{
NBS TECHNICAL NOTE 417 \\ ISSUED MARCH 1968
}

\section{Spectral Emission Properties of NBS Standard Phosphor Samples Under Photo-Excitation}

\author{
Carl F. Shelton
}

Metrology Division

Institute for Basic Standards

National Bureau of Standards

Washington, D.C. 20234

NBS Technical Notes are designed to supplement the Bureau's regular publications program. They provide a means for making available scientific data that are of transient or limited interest. Technical Notes may be listed or referred to in the open literature. 


\section{Contents}

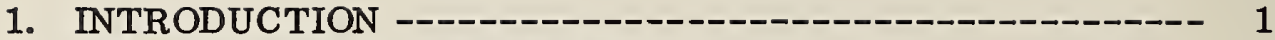

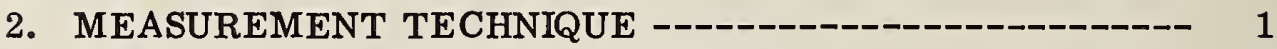

3. COMPUTER CORRECTION OF DATA --_-_---_---_---- 3

3. 1 Results --

4. RELATIVE QUANTUM EFFICIENCY --------------- 26

RE FERENCES --_-_-_-_-_-_-_- 29 


\section{SPECTRAL EMISSION PROPERTIES OF NBS STANDARD \\ PHOSPHOR SAMPLES UNDER PHOTO-EXCITATION}

Car1 F. She1ton*

The photo-excitation spectral emission properties of 10 of the 14 NBS standard phosphor samples have been determined. Pressed tablets of the phosphors were excited by radiation from a mercury arc lamp, passing through a narrow band-pass filter to obtain either $2537 \AA$ or $3650 \AA$ excitation. The measurement system is described, correction of the data is discussed, and the spectral emission data are presented. Relative quantum efficiencies were calculated. The results are compared with measurements reported by two other laboratories.

Key Words: Phosphors, photo-excitation, photoluminescence, spectral emission, spectral radiometry, standard phosphor samples.

\section{Int roduction}

The spectral emission properties of ten NBS standard phosphor samples under ultraviolet excitation have been measured. The phosphors and the exciting radiation used are listed in Table $I$. The relative quantum efficiencies of the $2537 \AA$ excited phosphors were calculated relative to magnesium tungstate from the data obtained.

The purpose of this report is to describe the measurement technique used, to discuss a computer program written to reduce the raw data, and to present the results obtained.

\section{Measurement Technique}

Measurements of the relative spectral emission of the phosphor samples under photo-excitation were made with the equipment shown in Figure 1 . The phosphor powder sample to be measured was placed in a small cup made of aluminum ( 1.25 inches in diameter and approximately 0.04 inch deep) and pressed level by using a spatula. This phosphor plaque was then placed on a turret sample holder mounted horizontally in front of the monochromator which was mounted vertically.

A 4-watt low-pressure mercury-arc lamp (germicidal) was used as source for $2537 \AA$ excitation with a filter (Corning No. 9863) in front of the $1 \mathrm{amp}$ to block the mercury lines in the visible region. A 100-watt high-pressure mercury-arc lamp with a narrow-band-pass filter centered at $3650 \AA$, in front

*Research Associate from the International Business Machines Corporation at the National Bureau of Standards, 1967. 
TABLE I

Sample Measurement

\begin{tabular}{|c|c|c|c|}
\hline No. & Excitation ( $(\AA)$ & Phosphor Description & Use \\
\hline 1020 & 3650 & $\begin{array}{l}\text { Zinc Sulfide } \\
\mathrm{ZnS}: \mathrm{Ag}\end{array}$ & $\begin{array}{l}\text { Blue Component of } \\
\text { P-4 Cathode Ray Tube } \\
\text { (CRT) Phosphor }\end{array}$ \\
\hline 1021 & 2537 & $\begin{array}{l}\text { Zinc Silicate } \\
\mathrm{Zn}_{2} \mathrm{SiO}_{4}: \mathrm{Mn}\end{array}$ & P-1 CRT Phosphor \\
\hline 1022 & 3650 & $\begin{array}{l}\text { Zinc Sulfide } \\
\text { ZnS:Cu }\end{array}$ & P-2 CRT Phosphor \\
\hline 1023 & 3650 & $\begin{array}{l}\text { Zinc-Cadmium Sulfide } \\
\text { ZnCdS:Ag }\end{array}$ & $\begin{array}{l}\text { Yellow Component of } \\
\text { P-4 CRT Phosphor }\end{array}$ \\
\hline 1024 & 3650 & $\begin{array}{l}\text { Zinc-Cadmium Sulfide } \\
\text { ZnCdS:Cu }\end{array}$ & $\begin{array}{l}\text { Orange Component of } \\
\text { P-14 CRT Phosphor }\end{array}$ \\
\hline 1025 & $----(1)$ & $\begin{array}{l}\text { Zinc Phosphate } \\
\mathrm{Zn}_{3}\left(\mathrm{PO}_{4}\right)_{2}: \mathrm{Mn}\end{array}$ & $\begin{array}{l}\text { Red Component of } \\
\text { P-22 CRT Phosphor }\end{array}$ \\
\hline 1026 & 2537 & $\begin{array}{l}\text { Calcium Tungstate } \\
\text { CaWO }_{4}: \mathrm{Pb}\end{array}$ & CRT, Lamps \\
\hline 1027 & 2537 & $\begin{array}{l}\text { Magnesium Tungstate } \\
\mathrm{MgWO}_{4}\end{array}$ & CRT, Lamps \\
\hline 1028 & 2537 & $\begin{array}{l}\text { Zinc Silicate } \\
\mathrm{Zn}_{2} \mathrm{SiO}_{4}: \mathrm{Mn}\end{array}$ & Lamps \\
\hline 1029 & 2537 & $\begin{array}{l}\text { Calcium Silicate } \\
\mathrm{CaSiO}_{3}: \mathrm{Pb}, \mathrm{Mn}\end{array}$ & Lamps \\
\hline 1030 & $----(2)$ & $\begin{array}{l}\text { Magnesium Arsenate } \\
(\mathrm{MgO})_{\mathrm{x}}\left(\mathrm{As}_{2} \mathrm{O}_{5}\right)_{\mathrm{y}}: \mathrm{Mn}\end{array}$ & Lamps \\
\hline 1031 & 2537 & $\begin{array}{l}\text { Calcium Halophosphate } \\
3 \mathrm{Ca}{ }_{3}\left(\mathrm{PO}_{4}\right) \cdot \mathrm{Ca}(\mathrm{F}, \mathrm{Cl}): \mathrm{Sb} ; \mathrm{Mn}\end{array}$ & Lamps \\
\hline 1032 & $----(3)$ & $\begin{array}{l}\text { Barium Silicate } \\
\operatorname{BaSi}_{2} 0_{5}: \mathrm{Pb}\end{array}$ & Lamps (UV) \\
\hline 1033 & $----(3)$ & $\begin{array}{l}\text { Calcium Phosphate } \\
\mathrm{Ca}_{3}\left(\mathrm{PO}_{4}\right)_{2}: \mathrm{T} 1\end{array}$ & Lamps (UV) \\
\hline
\end{tabular}

(1) Would not emit under $2537 \AA$ or $3650 \AA$ excitation

(2) Fine emission structure not resolved with $5 \AA$ pass band of monochromator used; results not reported

(3) Not measured. 
of the lamp, was used as a source of $3650 \AA$ excitation. The output of the monochromator was measured by using a photomultiplier tube (PMT) with an S-20 photocathode (Dumont EM2433), an amplifier or a picoammeter, and a digital voltmeter as shown in Figure 1 .

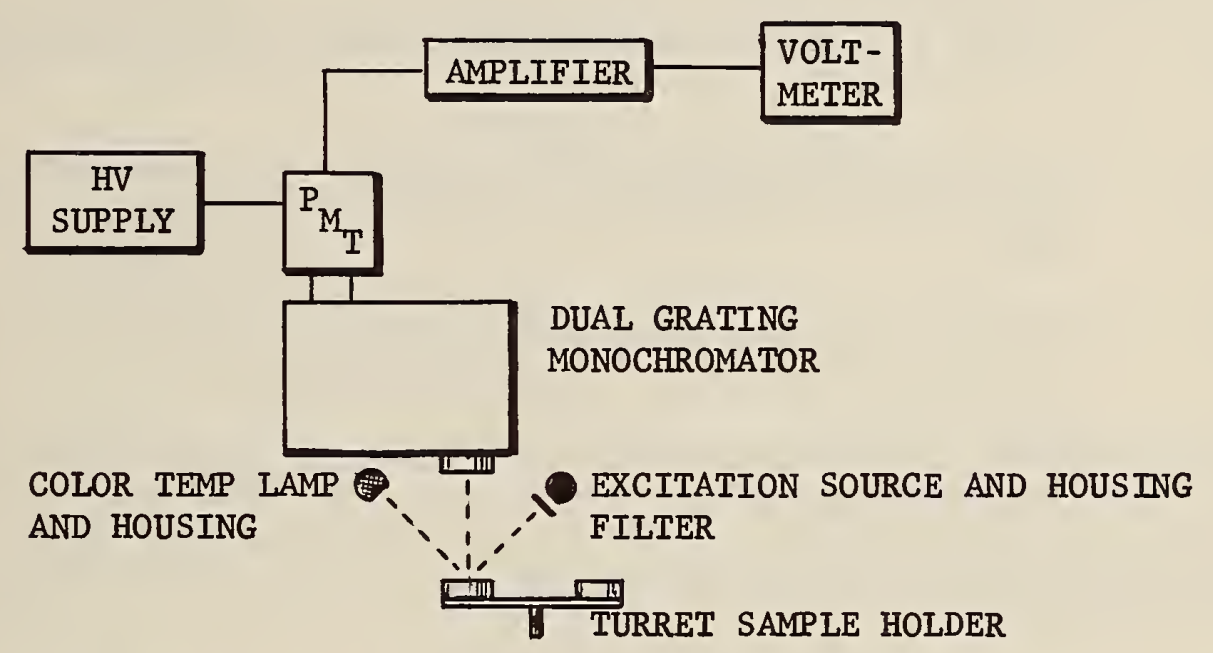

Figure 1 Spectral Measurement Equipment

In order to calibrate the monochromator and PMT combination, its relative spectral sensitivity was measured by using an NBS color temperature standard operated at a color temperature of 2854K. A USP grade barium sulfate (standard reflector) plaque was placed on the turret sample holder 80 that it could be rotated into position in front of the entrance slit of the monochromator. The spectral radiant flux of the color temperature 8 tandard, as diffusely reflected by the plaque, was used to calibrate the equipment.

A measurement of the phosphor sample consisted of setting the monochromator at a particular wavelength (scale readable to three places), and recording the digital voltage reading; first, with the color temperature lamp and the $\mathrm{BaSO}_{4}$ plaque; and second, with the excitation source and the phosphor sample in front of the entrance slit. Both lamps were housed and shuttered such that they could be left on continuously during a data run and used independently. The wavelength scale on the monochromator was verified by using the mercury lines in the low pressure excitation source.

\section{Computer Correction of Data}

A computer program was used to calculate the relative spectral sensitivity of the instrument for each run and to apply calibration corrections to the data obtained in order to obtain the relative spectral distribution of the phosphor photo-luminescence for each data run. The corrected phosphor relative radiant energy distribution curves for several independent runs were then averaged over the number of runs to provide an average curve for each phosphor measured. 
The following quantities are defined:

$\mathrm{N} \quad \equiv$ Number of data runs for each phosphor

$\lambda_{j} \quad \equiv$ Wavelength value: $j=1, \ldots, 20$

$\mathrm{s}_{i}\left(\lambda_{j}\right) \equiv \begin{aligned} & \text { Relative sensitivity of instrument for the } i-t h \text { data run } \\ & \mathbf{i}=1, \ldots, \mathrm{N}\end{aligned}$

$C_{i}\left(\lambda_{j}\right) \equiv$ Digital voltage reading when using color temperature lamp and $\mathrm{BaSO}_{4}$ plaque for the $i$-th data run at the $j$-th wavelength value

$\begin{aligned} L\left(\lambda_{j}\right) \equiv & \text { Relative spectral luminance of } \mathrm{BaSO}_{4} \text { plaque when irradiated } \\ & \text { by color temperature standard }(2854 \mathrm{~K}) .\end{aligned}$ $\begin{aligned} D_{i}\left(\lambda_{j}\right) \equiv & \begin{array}{l}\text { Digital voltage reading when using excitation source and } \\ \text { phosphor plaque. }\end{array}\end{aligned}$

Thus, since $C_{1}\left(\lambda_{j}\right)$ is by definition

$$
C_{1}\left(\lambda_{j}\right)=s_{i}\left(\lambda_{j}\right) L\left(\lambda_{j}\right),
$$

the relative spectral sensitivity for the $i$-th data run is therefore

$$
s_{i}\left(\lambda_{j}\right)=\frac{c_{i}\left(\lambda_{j}\right)}{L\left(\lambda_{j}\right)}
$$

also by definition,

$$
D_{i}\left(\lambda_{j}\right)=s_{i}\left(\lambda_{j}\right) P_{i}\left(\lambda_{j}\right)
$$

whe re:

$P_{i}\left(\lambda_{j}\right) \equiv$. Relative radiant energy distribution of the phosphor for $i-t h$

Therefore,

$$
P_{i}\left(\lambda_{j}\right)=\frac{D_{i}\left(\lambda_{i}\right)}{S_{i}\left(\lambda_{j}\right)}=\frac{D_{i}\left(\lambda_{j}\right) L\left(\lambda_{j}\right)}{C_{i}\left(\lambda_{j}\right)}
$$

and the normalized distribution curve is given by,

where:

$$
\operatorname{NP}_{i}\left(\lambda_{j}\right)=\frac{P_{i}\left(\lambda_{j}\right)}{P_{i_{\text {Max }}}}
$$

$$
P_{i_{\text {Max }}} \equiv \text { Maximum value of } P_{i}\left(\lambda_{j}\right) \text { for } j=1, \ldots, 20
$$

and the average relative energy distribution over the $\mathrm{N}$ data runs for each phosphor is finally

$$
P_{\text {ave }}\left(\lambda_{j}\right)=\frac{\sum_{i=1}^{N} N P_{i}\left(\lambda_{j}\right)}{N}
$$


The relative energy distribution curves obtained for the ten phosphors measured are shown in figures 2 to 11 . Each figure is followed by its computer output data, in Tables 2 to 11, showing the tabular values for each curve. The average curve for each phosphor is plotted and the tabular values are given on each curve. The tabular values shown are $95 \%$ confidence interval estimates of the true mean, calculated as:

$$
\bar{x} \pm \tau_{n} w
$$

where: $\quad \mathrm{w}=$ range (maximum value minus minimum value)

$\mathrm{n}=$ sample size

$\overrightarrow{\mathrm{x}}=$ computed mean of sample

and values of $\tau_{n}$ are given in Table $8 c(1)$, page 408 , of Ref. 5 .

The relative energy distribution curves obtained for Sample Nos. 1020, 1022, 1023 and 1024 with photo-excitation are compared with data obtained with cathode-ray excitation by Bril (Ref. 2). Sample 1022 is a P-2 phosphor and the JEDEC $\mathrm{P}-2$ data $(\operatorname{Re} \mathrm{f} 3$ ) is compared with the results obtained with photo-excitation.

The relative energy distribution curves obtained for Sample Nos. 1021 and 1026 with 2537 A excitation are, compared with results obtained by Bril (Ref 1) also with $2537 \AA$ excitation. While Sample No. 1021 compares very closely with Bril's data, Sample No. 1026 shows some differences. Sample Nos. 1026 and 1029 have been compared with data obtained in 1961 by Dr. Frank J. Studer at the Nela Park Laboratory of the General Electric Company (now at NBS). The two sets of data are in close agreement. Since Sample No. 1021 is a P-1 phosphor, the JEDEC $\mathrm{P}-1$ curve is also plotted from Ref. 3 .

The difference shown in comparing the results obtained with photo- and cathode-ray excitation are the same order of magnitude as the differences noted above obtained for Sample No. 1026 from data obtained with on $1 y$ photoexcitation, e.g., compare results for Sample No. 1024 where the results of photo and cathode ray excitation are shown, with Sample No. 1026. One might therefore hypothesize that the spectral emission curves are independent of the excitation used, but this hypothesis requires further investigation.

The tabular results show the repeatability of the measurements. In general, the results obtained with the low-pressure mercury-arc lamp (2537 $\AA$ excitation) are more repeatable than those obtained with the high-pressure $1 \mathrm{amp}$ ( $3650 \AA$ excitation) because of greater fluctuations of the output of the latter $1 \mathrm{amp}$.

Other measurement problems and sources of uncertainty include the low resolution of the wavelength scale on the monochromator (readable to only three places), the incomplete blocking of the mercury lines by the filter (preventing accurate readings near $4000 \AA$ with $2537 \AA$ excitation source), and the variations in the physical repositioning of the sample with the turret mount between data points. 


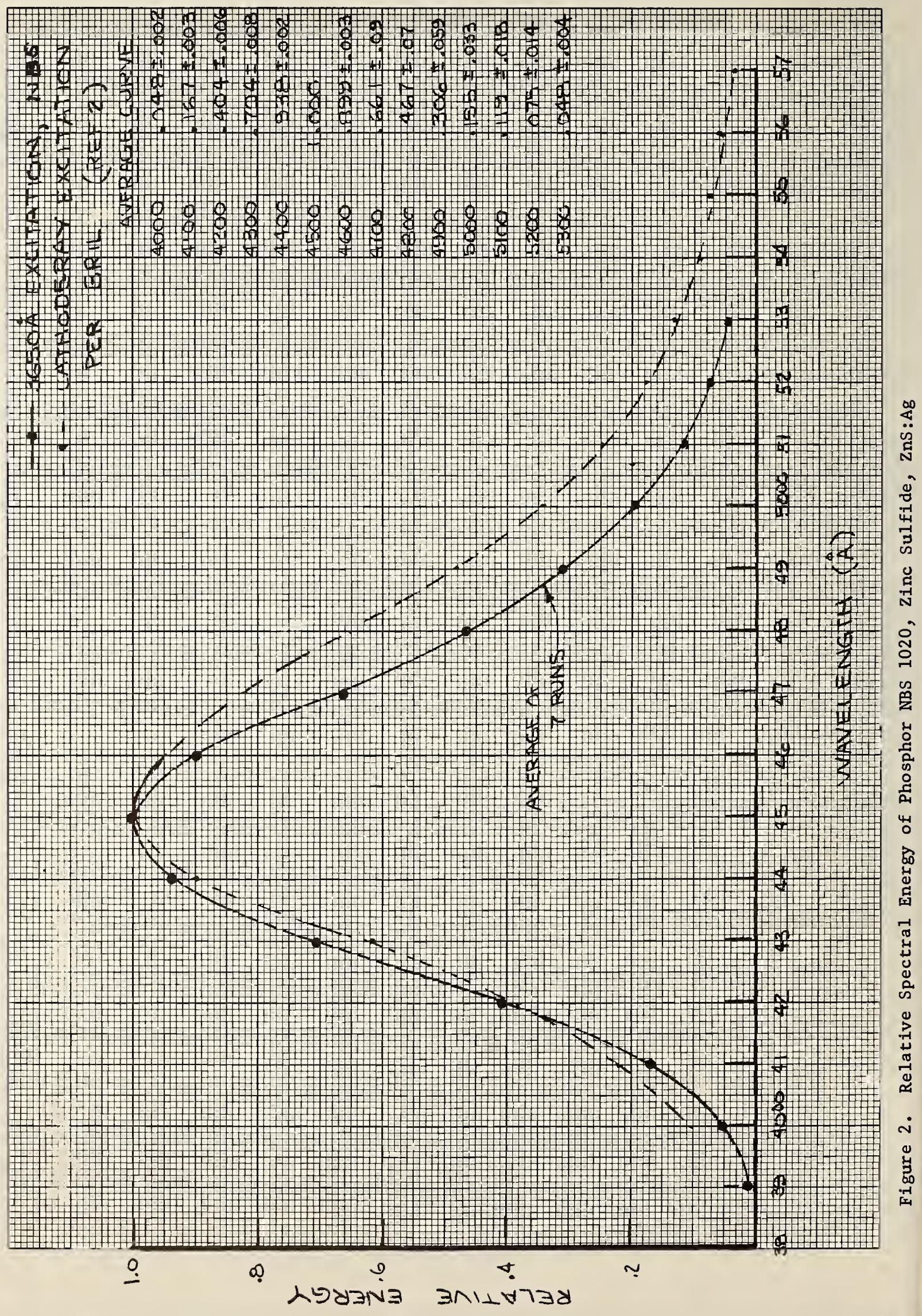




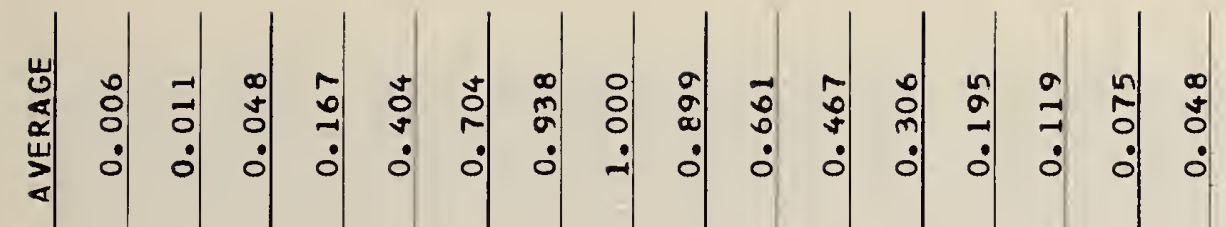

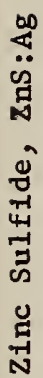

害 * $0 \dot{0} 0 \dot{0} 0 \dot{0} 0 \dot{0} 0 \dot{0} 0$

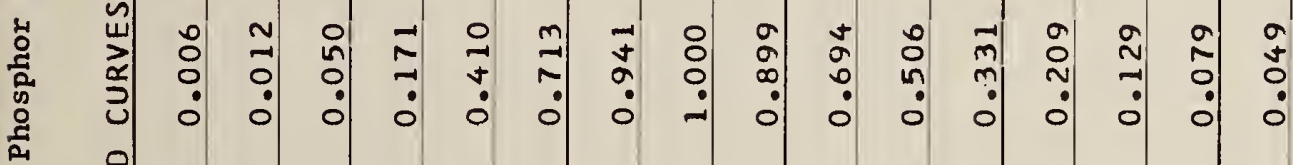

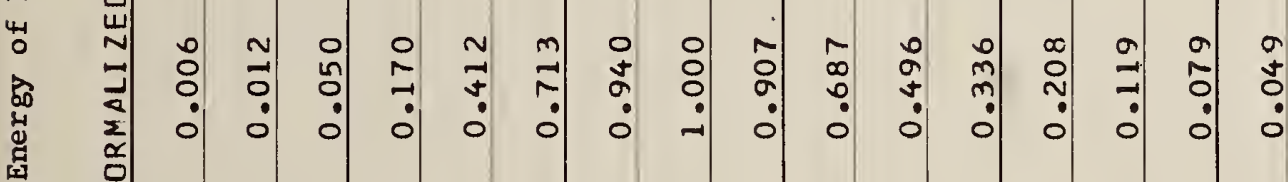


i ,

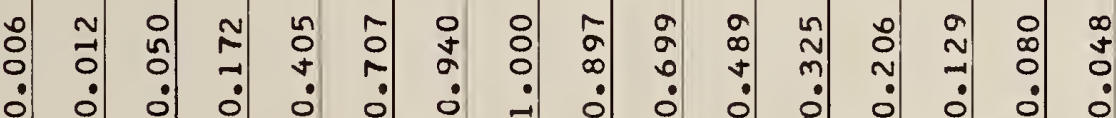

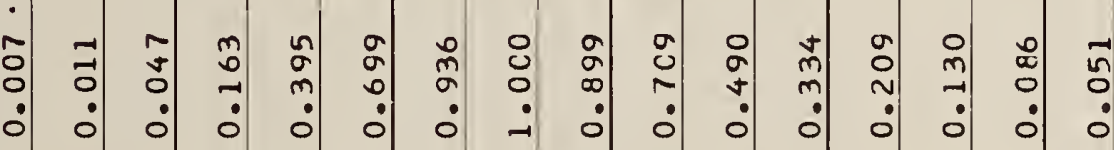

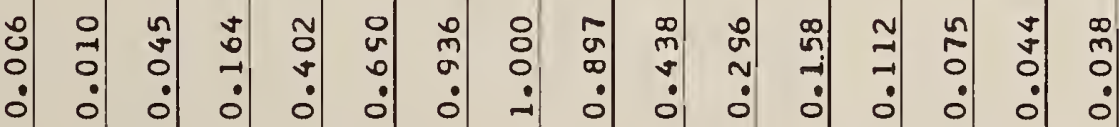

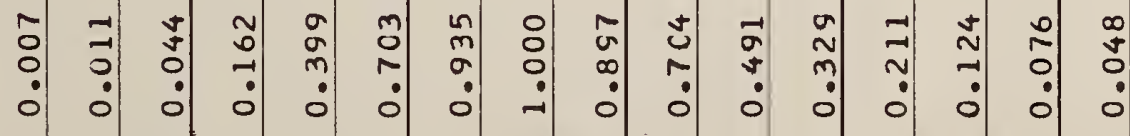
r

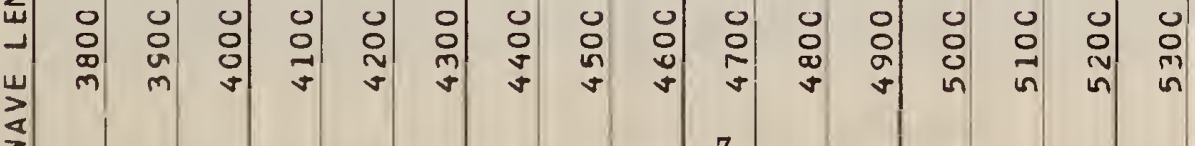




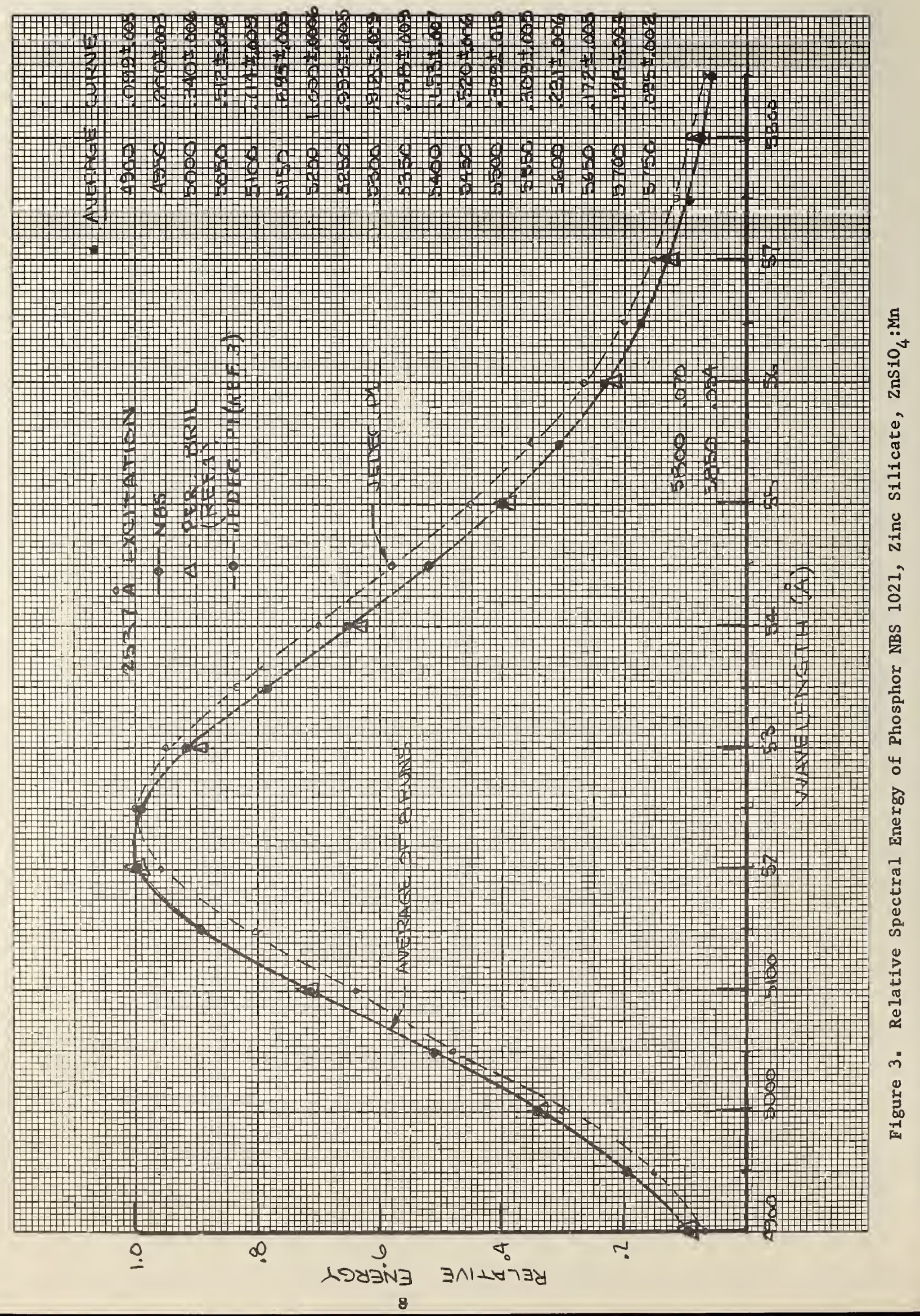




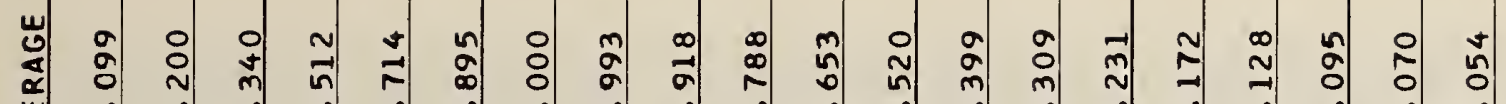

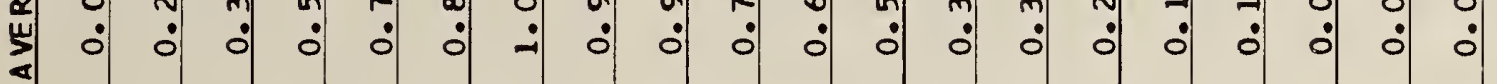

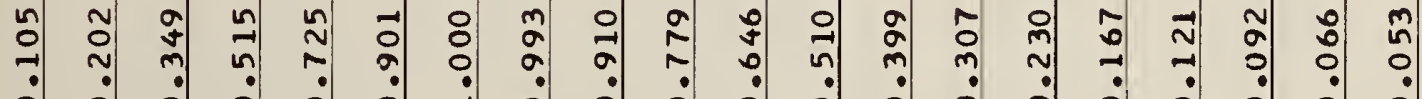
:

西

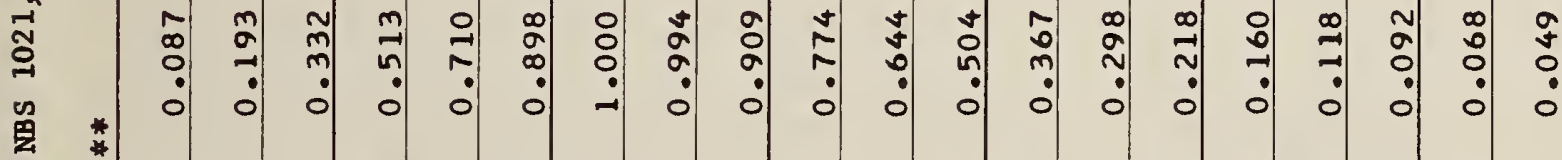

总 焉

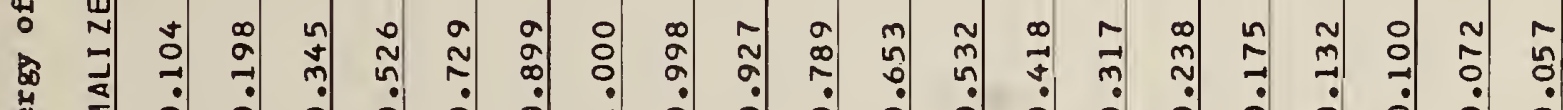
焉 -

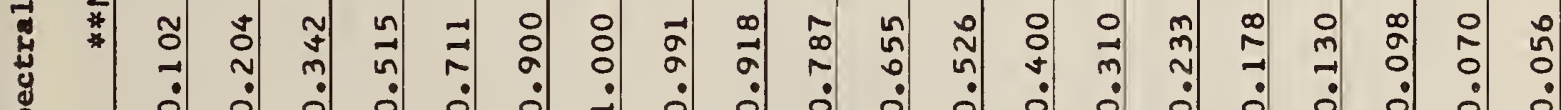

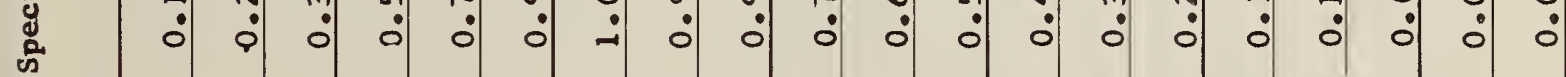
每

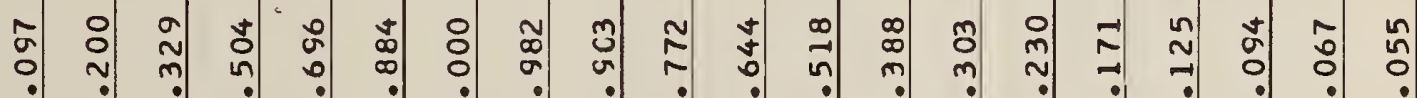

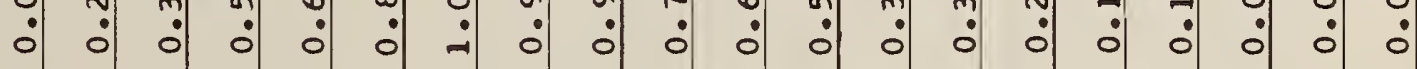
岁

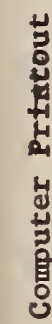

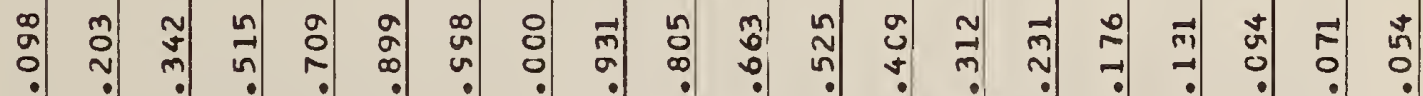

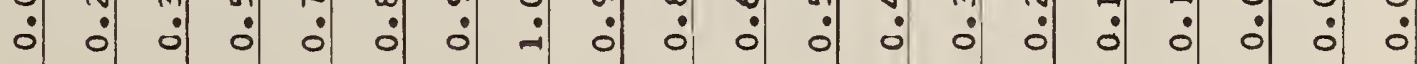

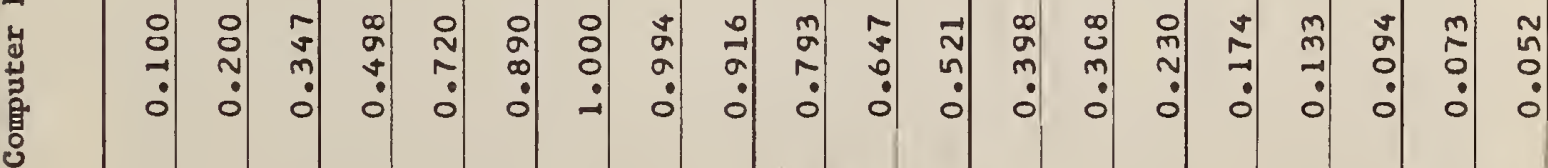

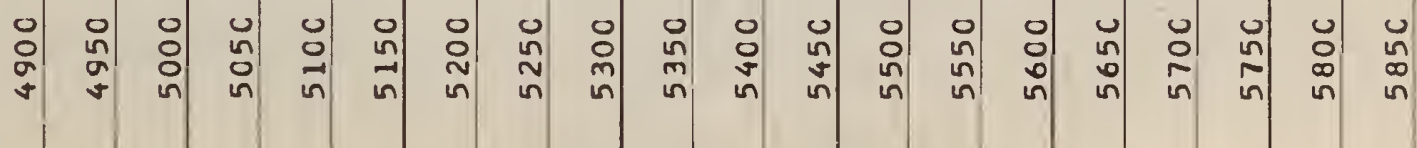




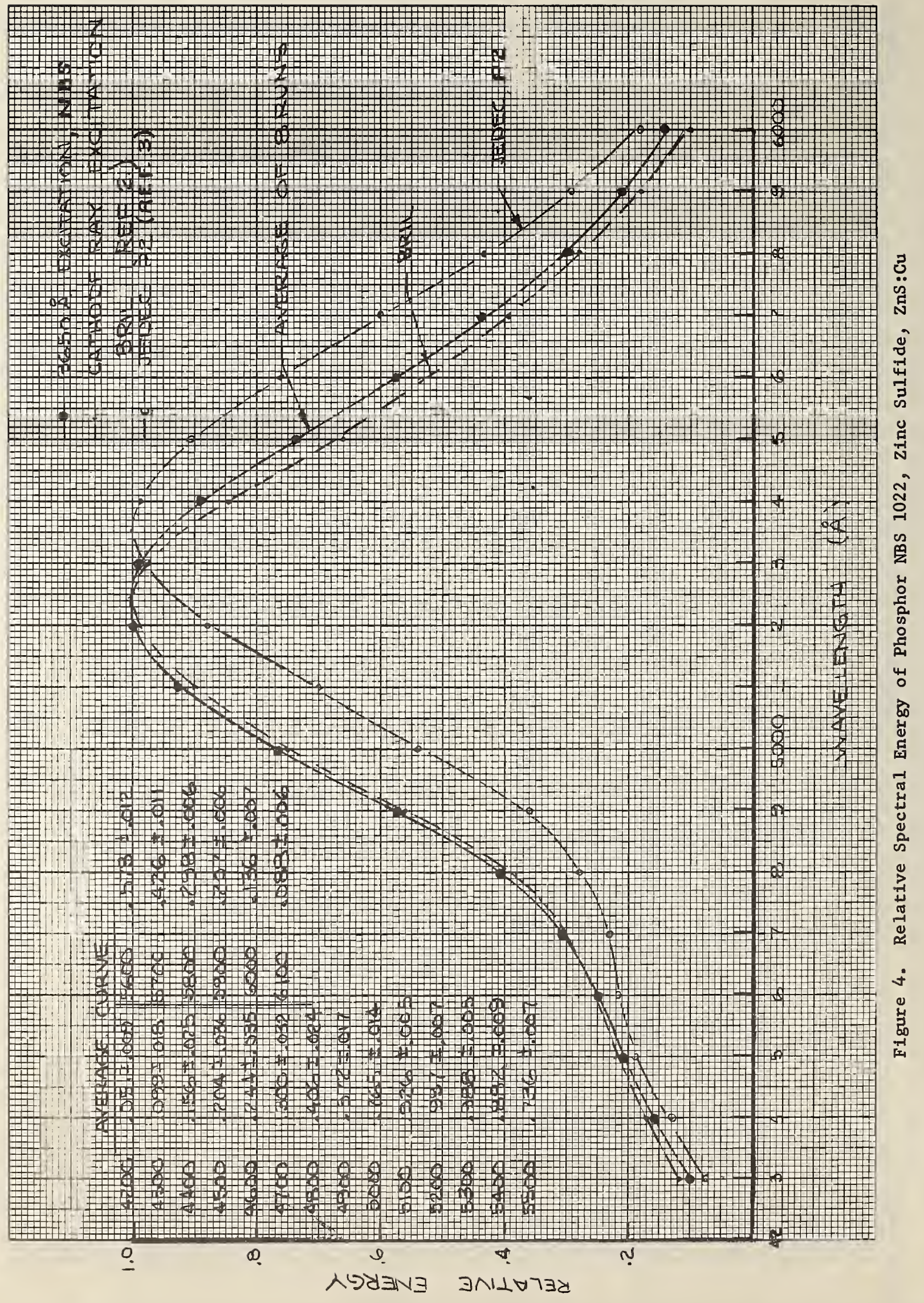




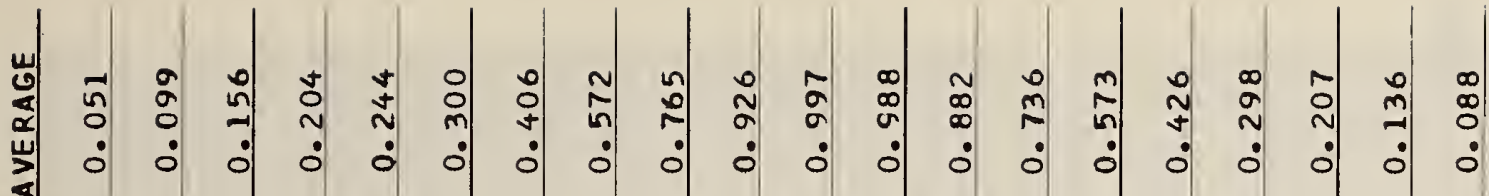
:

สิ

每

峛

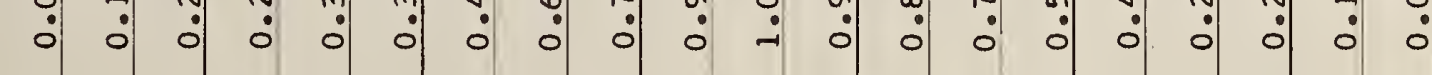

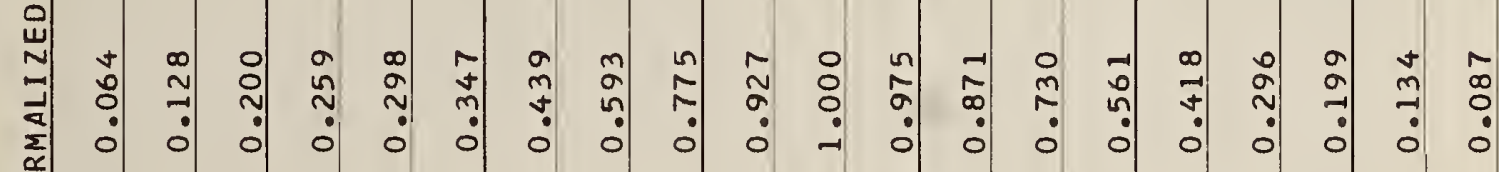
章

กิ

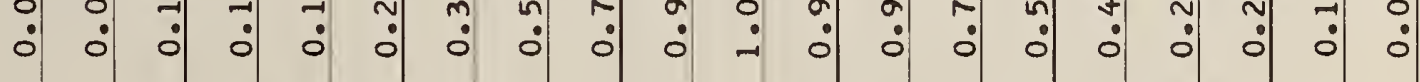

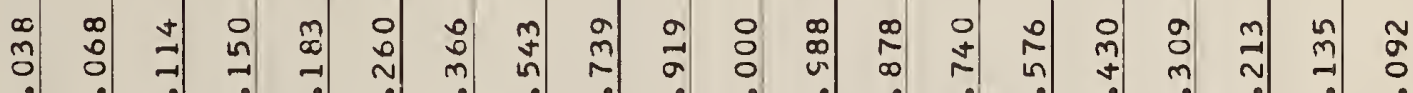

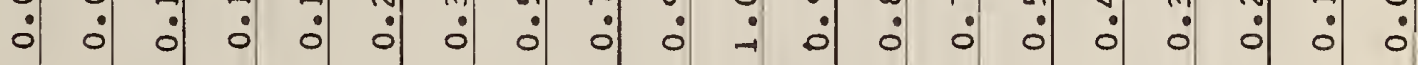
ஸी

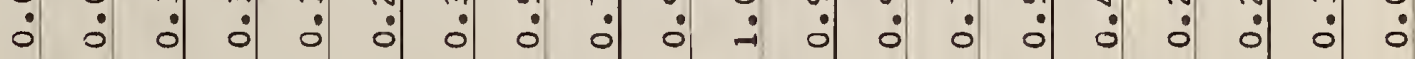

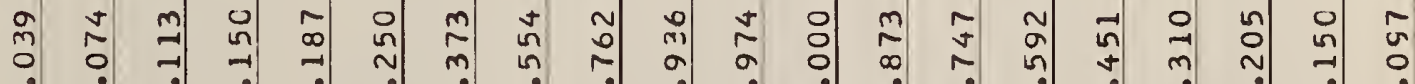

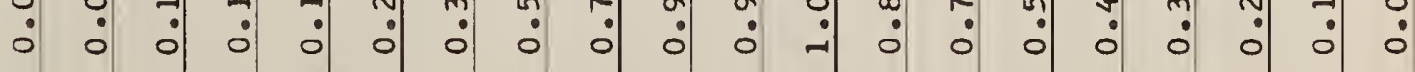

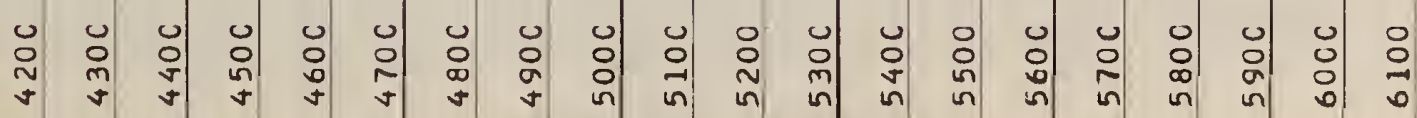


\&

3. $\left\{\begin{array}{l}3 \\ 3\end{array}\right.$ 8.6ว

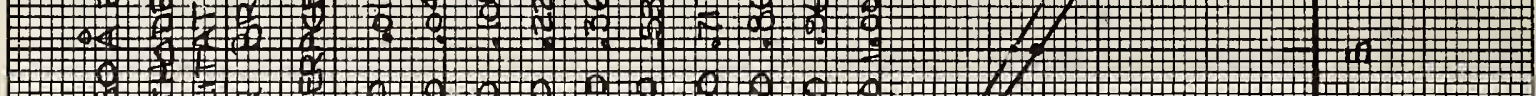
(2)

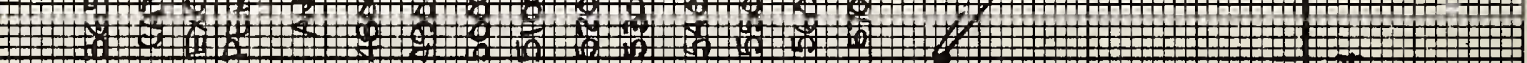
(1) /... $y / 2$

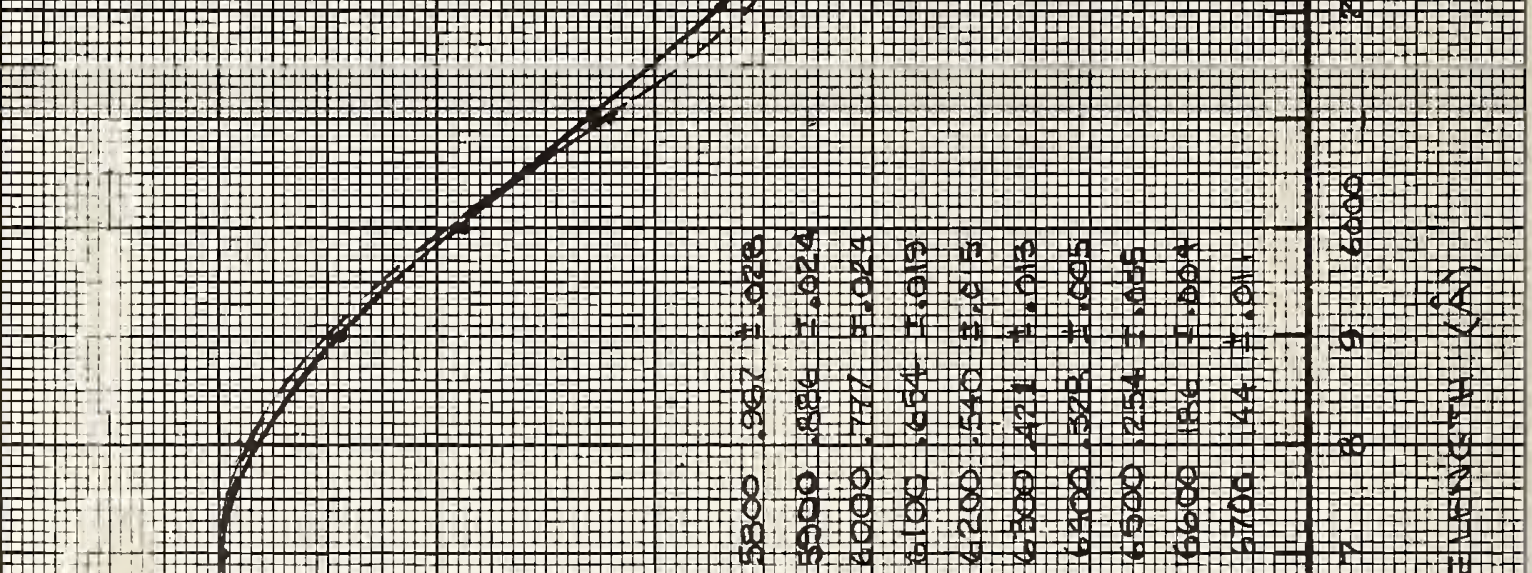
(- $-1, \frac{3}{3}$
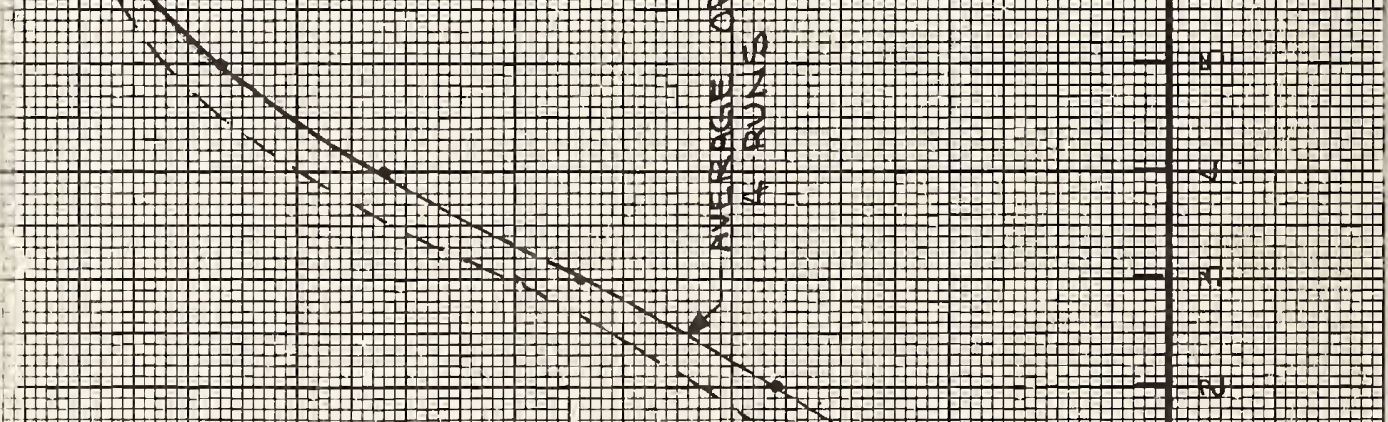

H

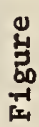

If

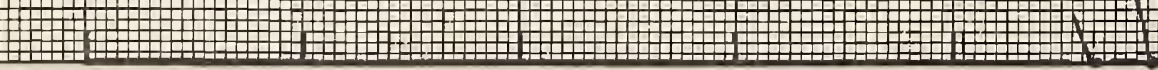




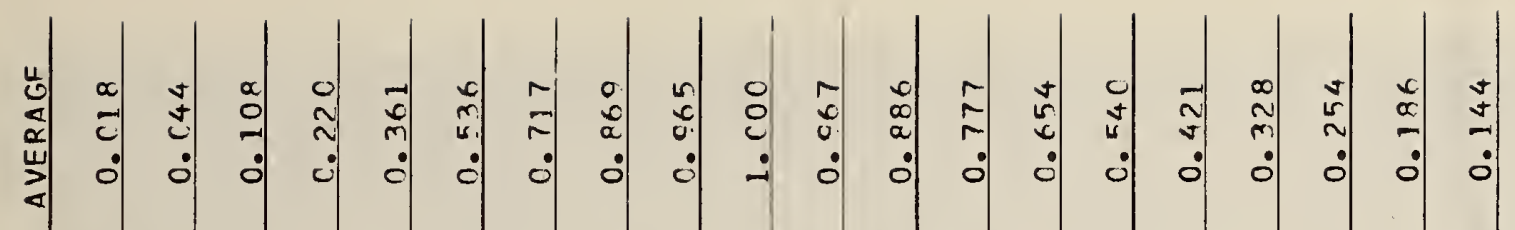

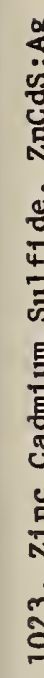

 


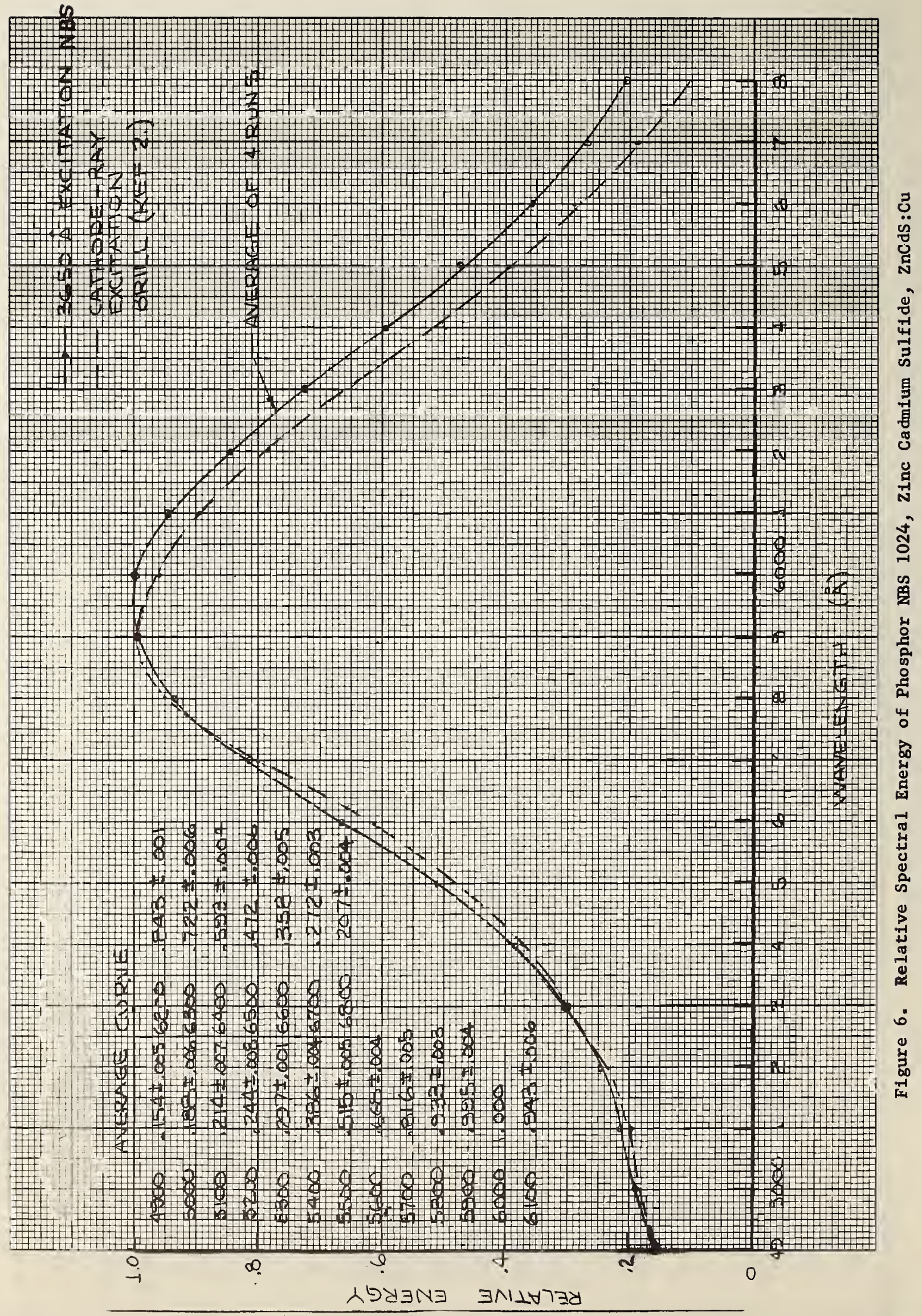









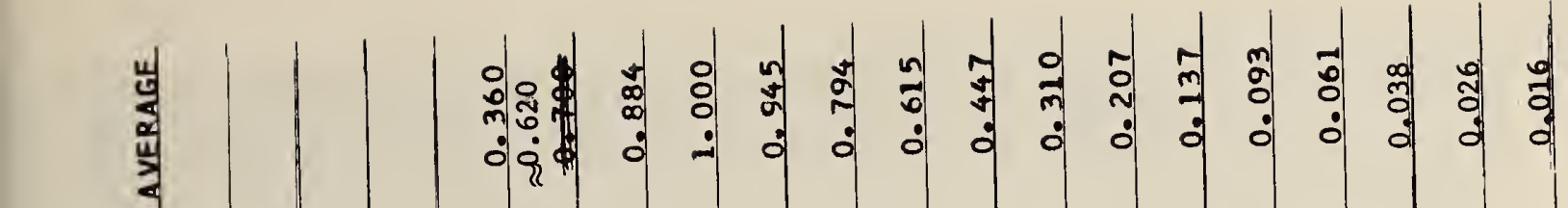

今àn

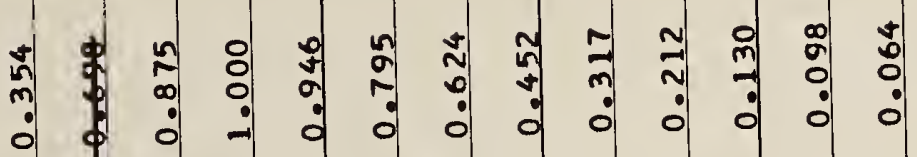

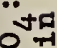

(1)

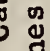

at

(a)

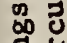

茛

具

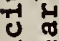

西

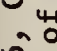

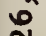

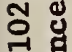

.

虫

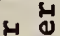

年

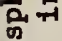

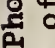

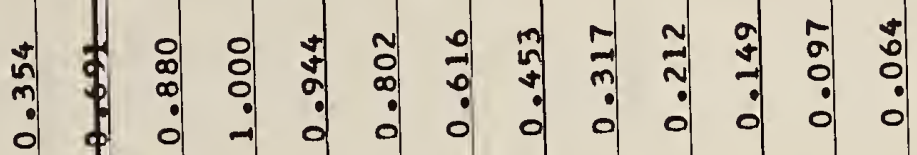

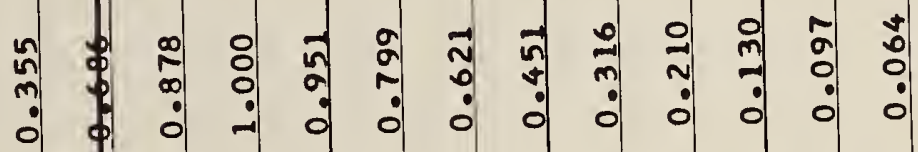

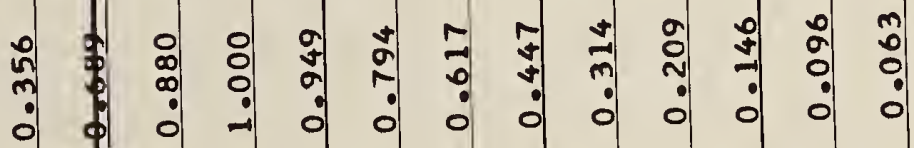

๓

$: \div \div: 00: 000$

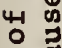

政

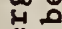

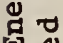

ता

त्-

8.

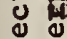

क人

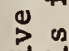

年

.

व:

品

嗐

+)

을

政

त d

.

H)

$+\infty 4$

a का के

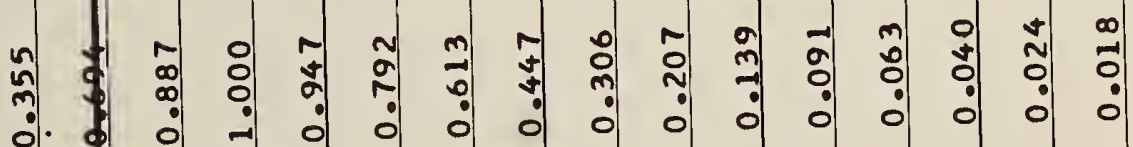

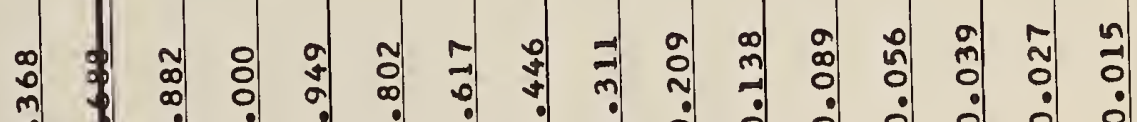

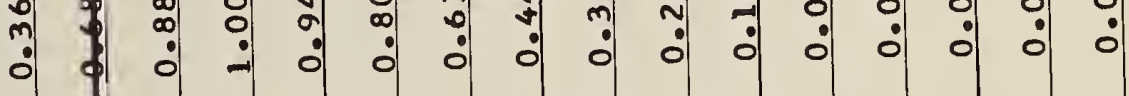

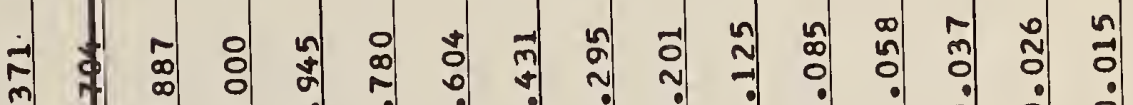

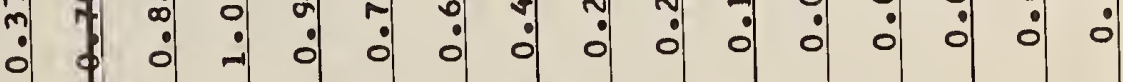

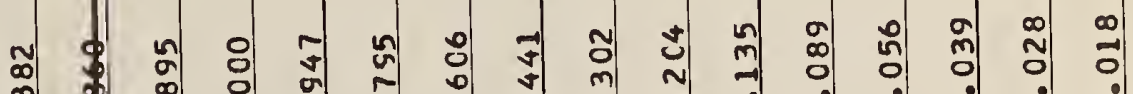

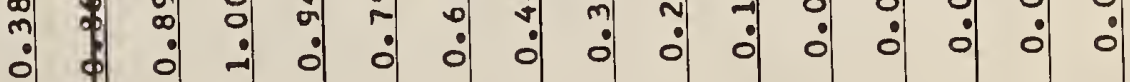

น

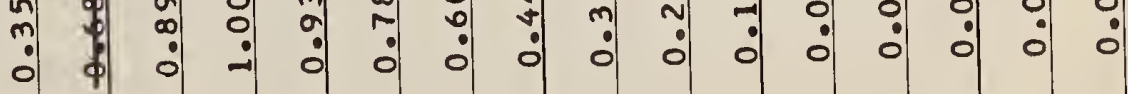

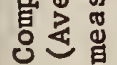

n

(a)

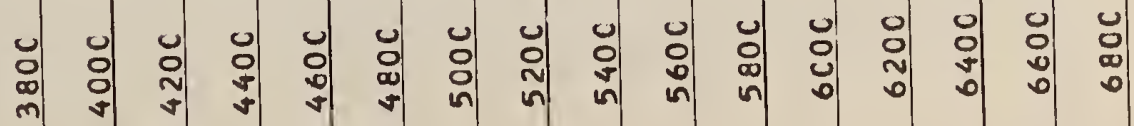




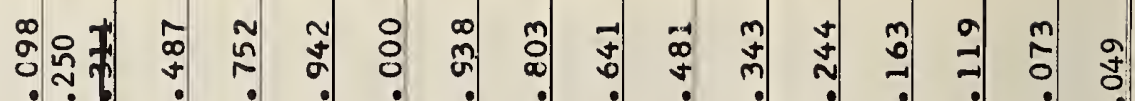
:

客舟

o

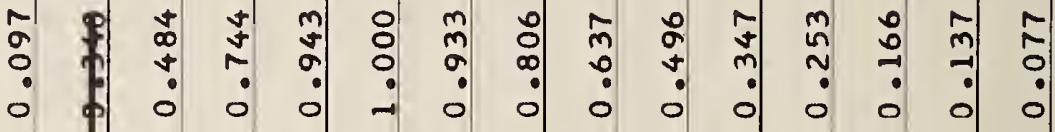

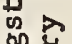

要

舟

目皆

实

वे

要

${ }^{2}$

ㄴ.

సิ

음

कs

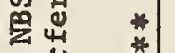

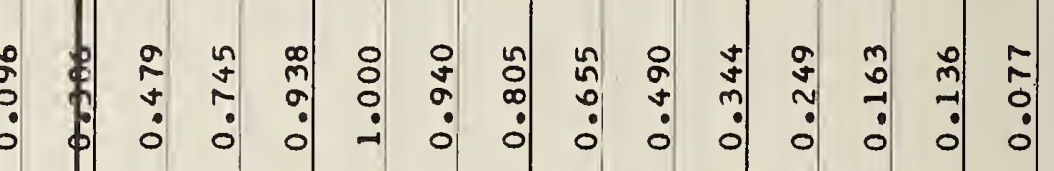

䔎岀

동

骂皆

4.

网

ڤั)

品

กี

둉

व

के प्र

$\sum_{-1}^{\infty} \infty$

iึ क्ञ

$\prod_{\rightarrow \rightarrow \infty}$

ฯ

嵴

岃

ว

क्ष क्ष

幽焉㟔

내일

4

宣资

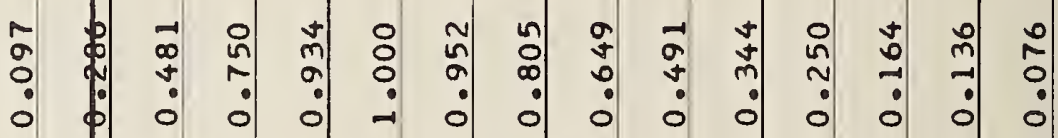

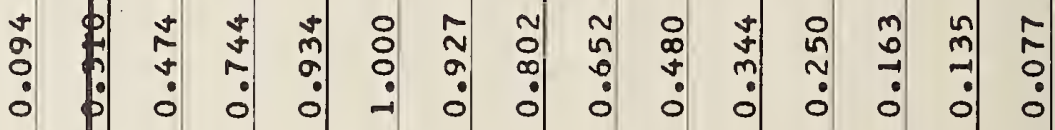

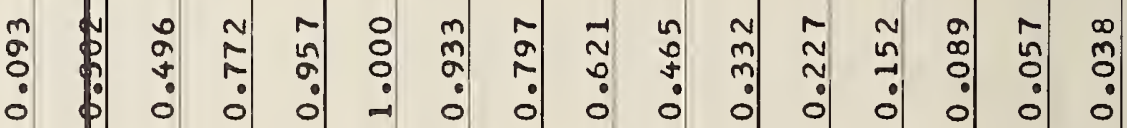

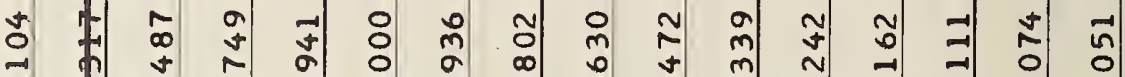

$\therefore$ :

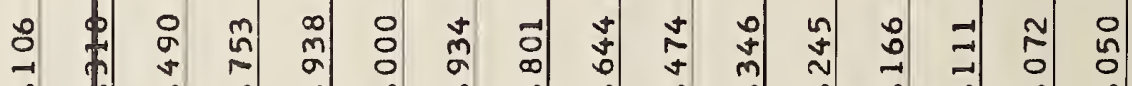

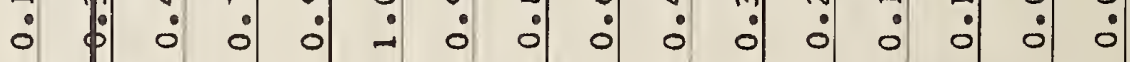

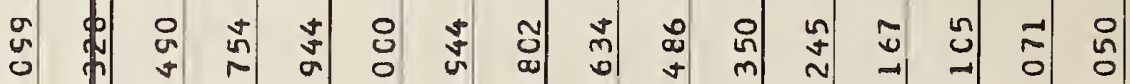

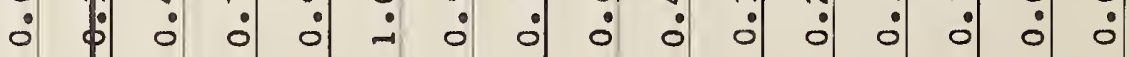

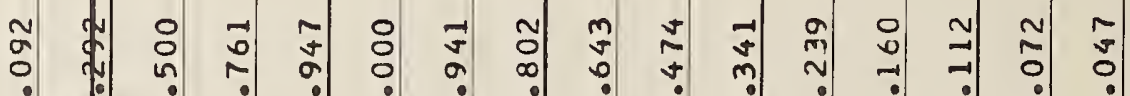

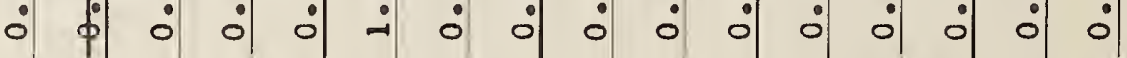

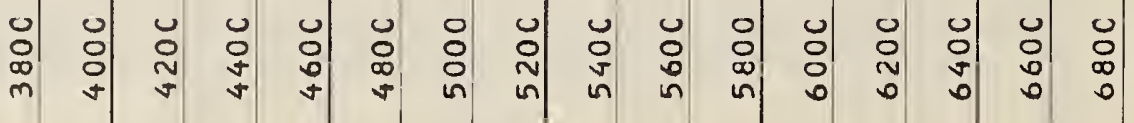




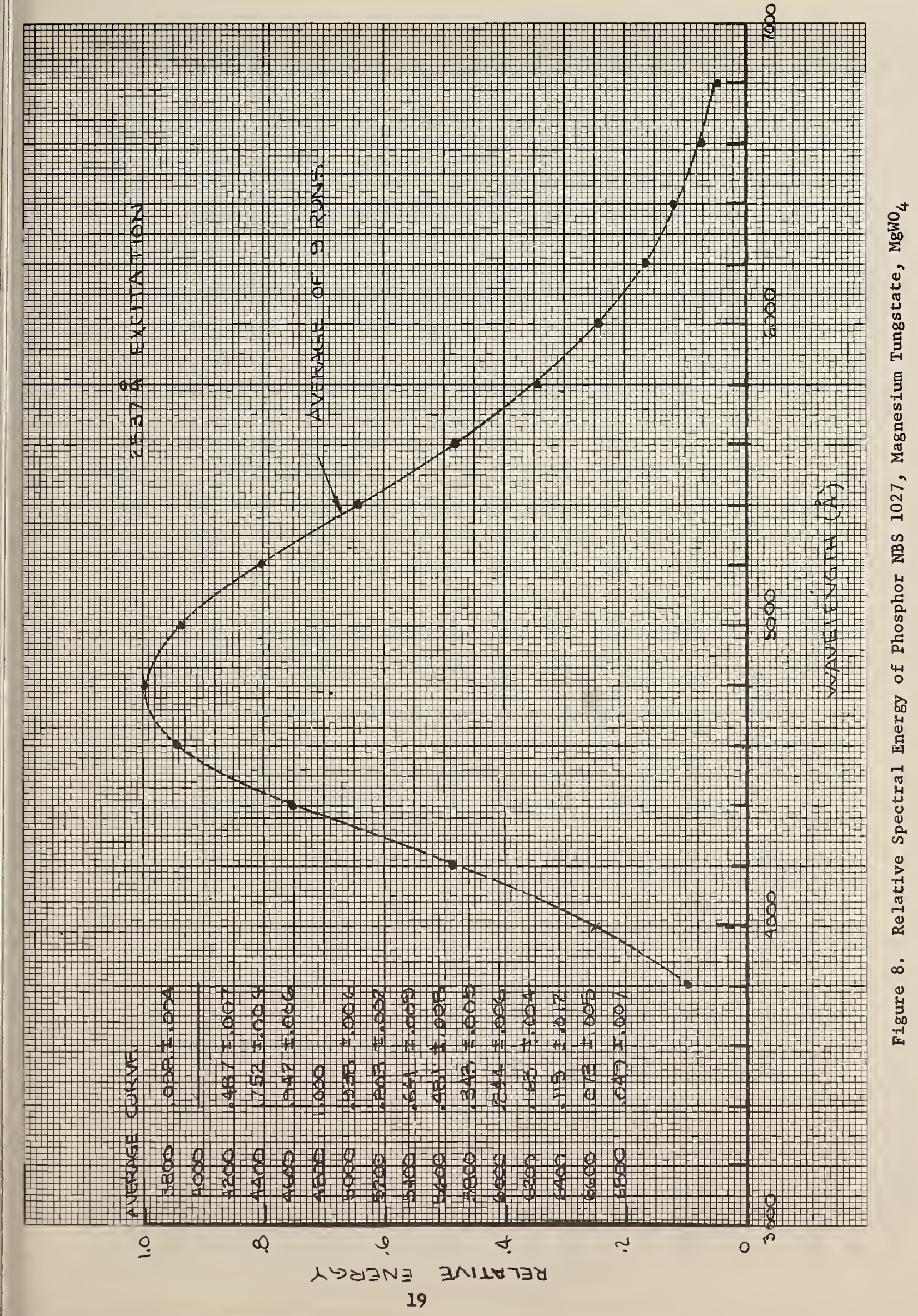




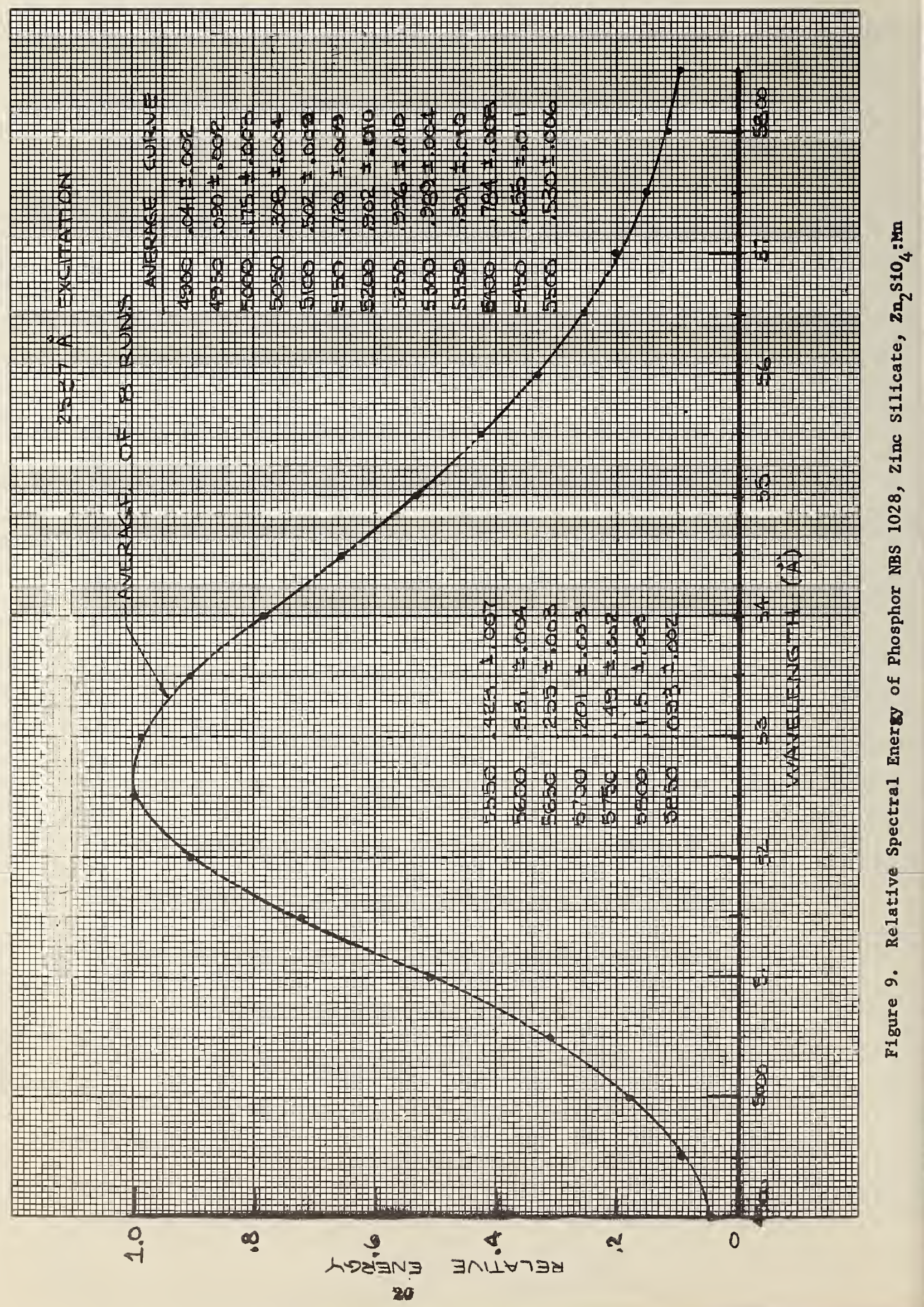




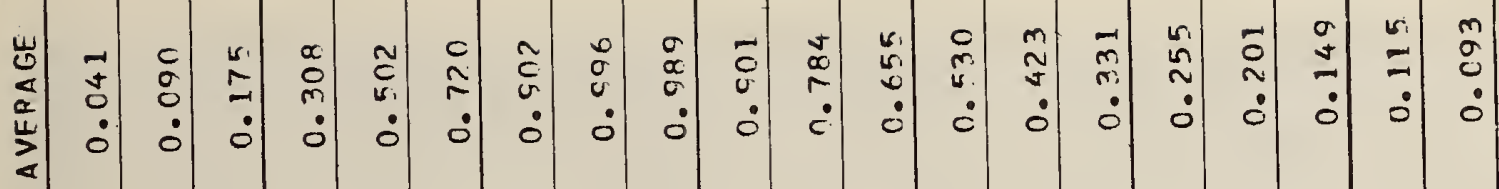

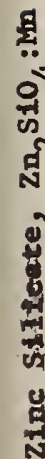

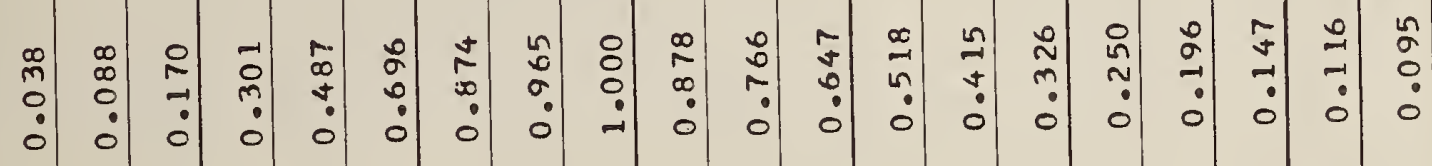

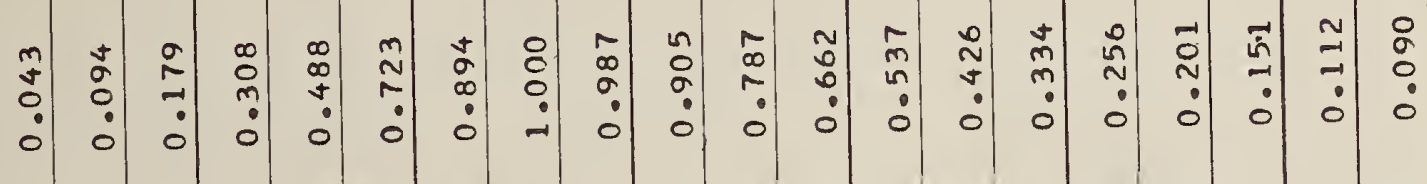
है

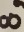

(2)

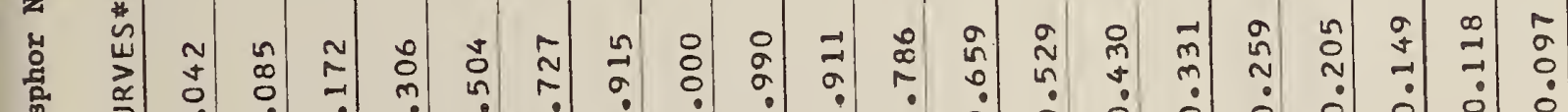
定

.

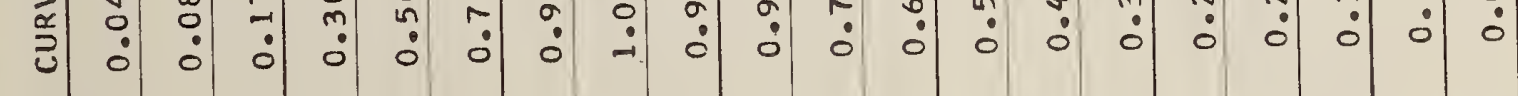

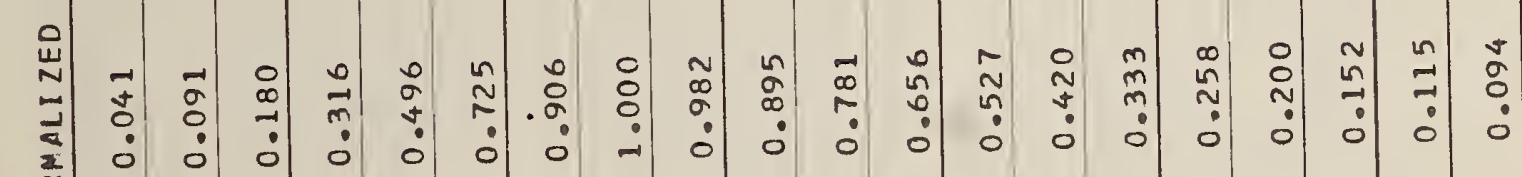

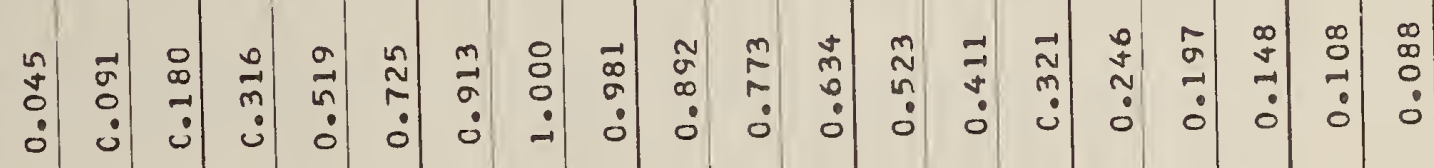

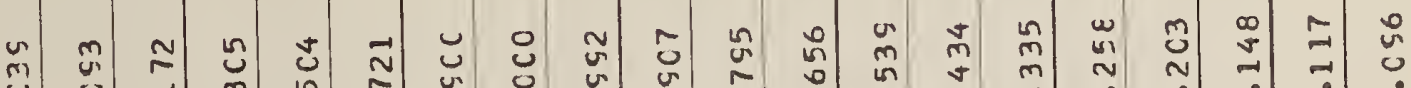

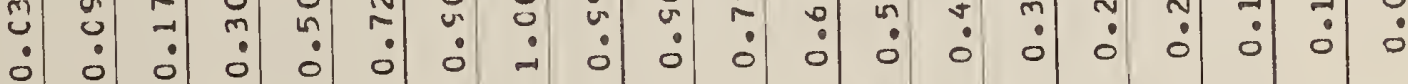
₹

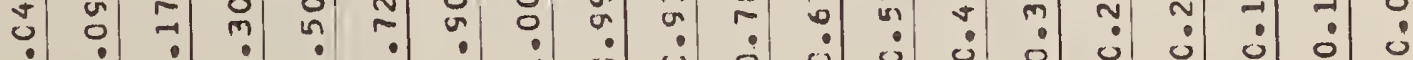

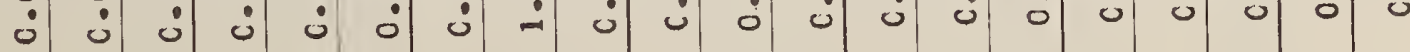

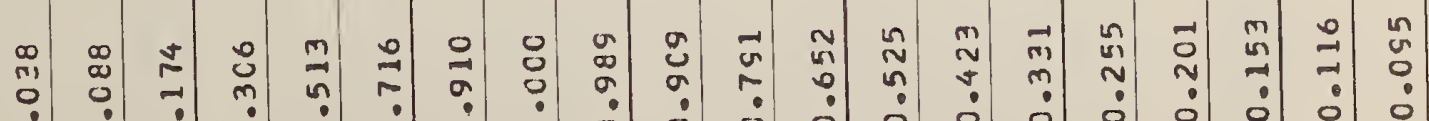

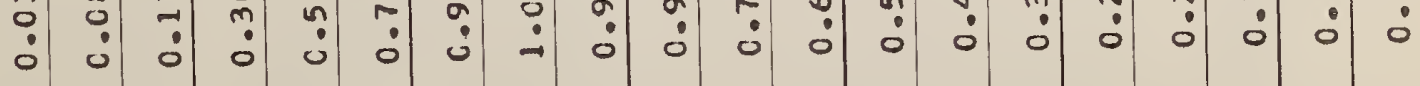

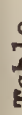

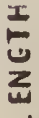

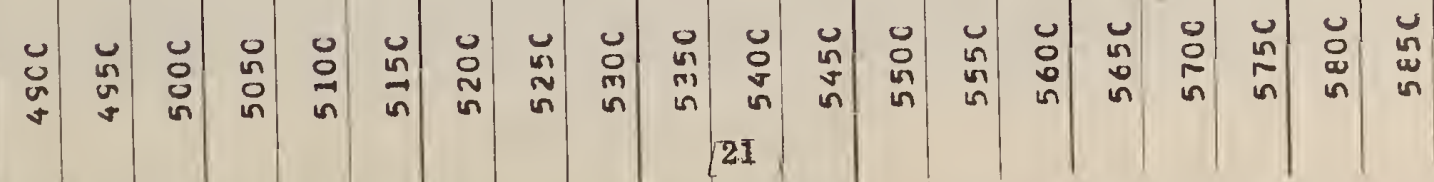
21 


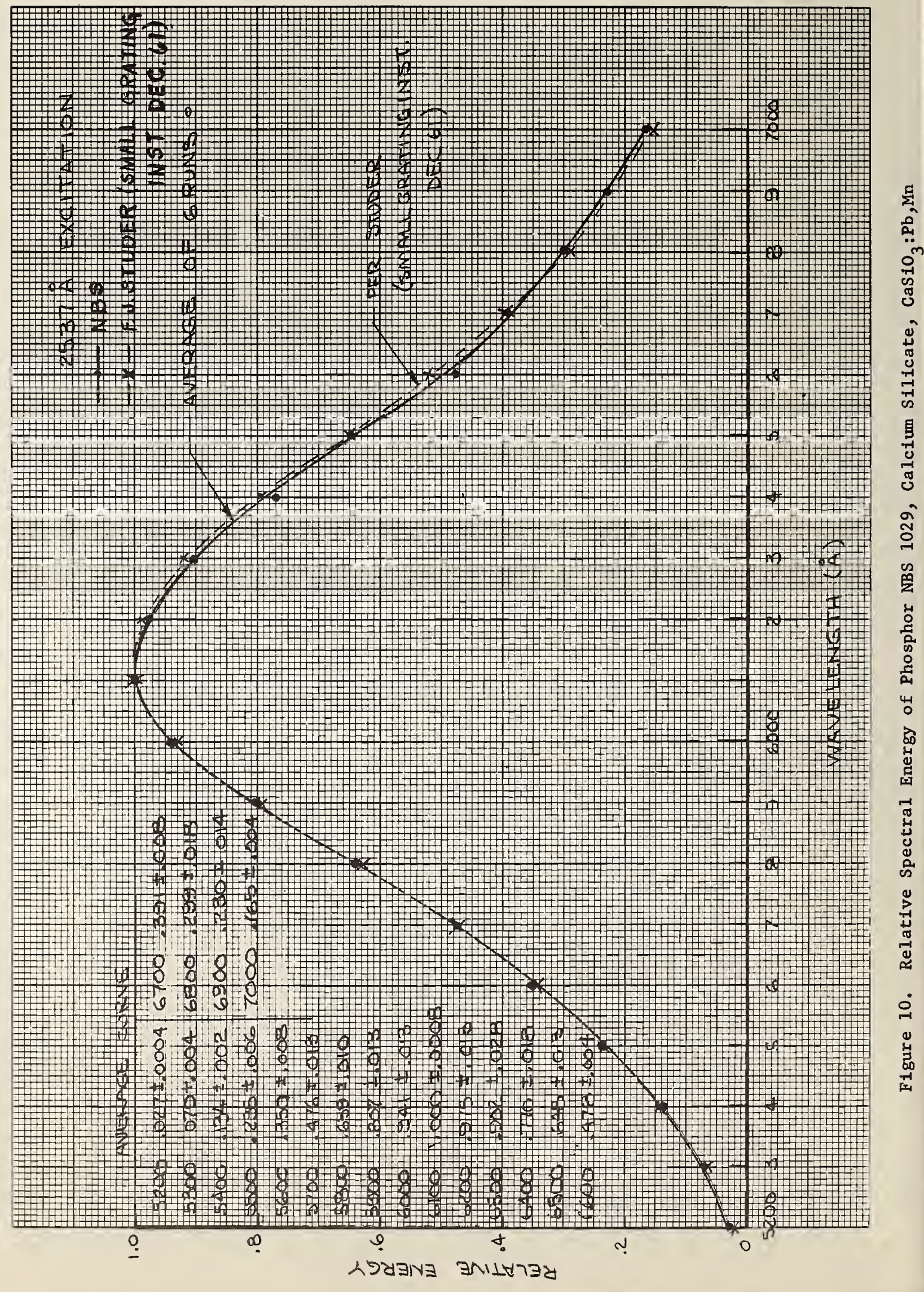




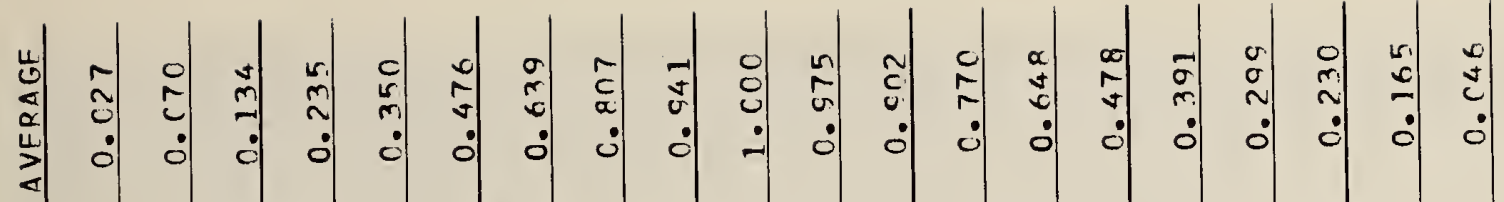

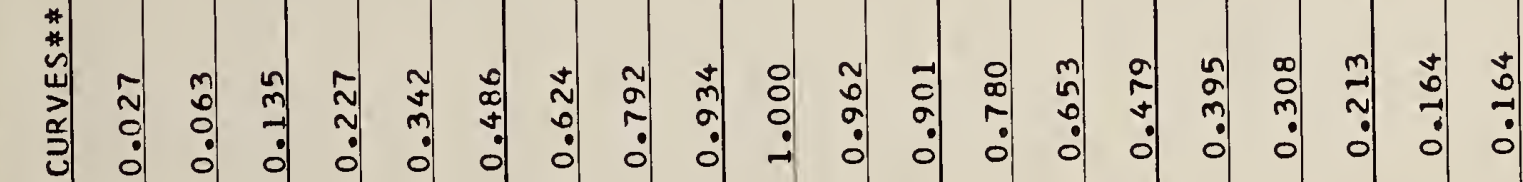
(1)

岂

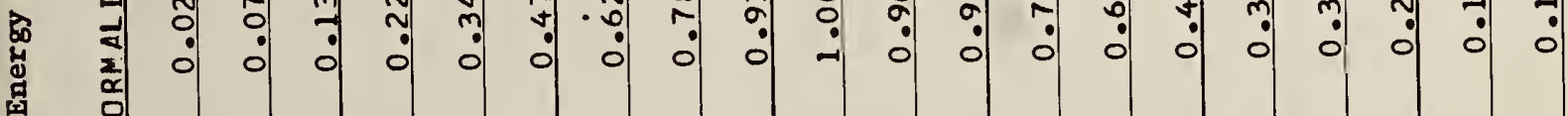
(1) సิ

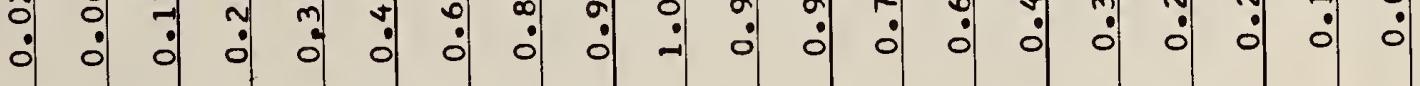

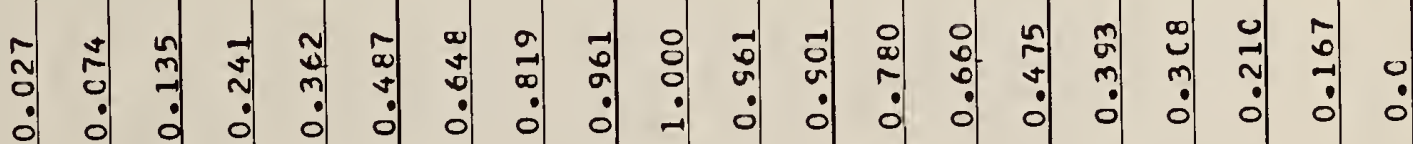

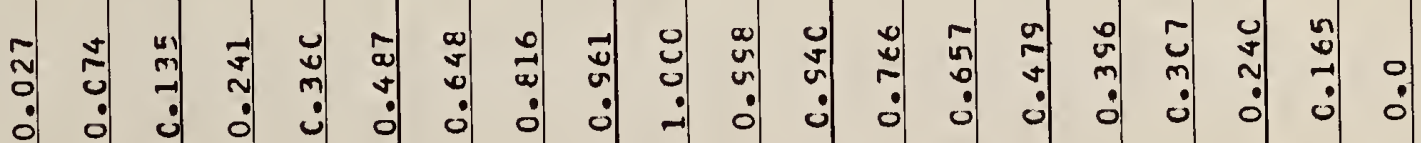

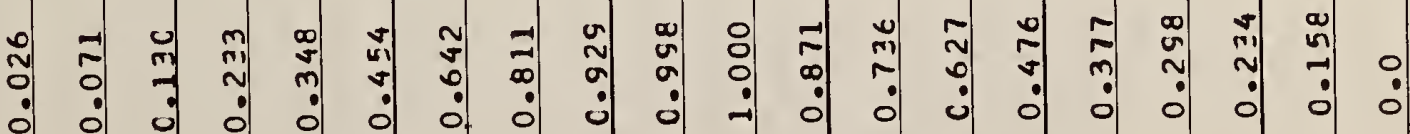
西 更

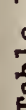

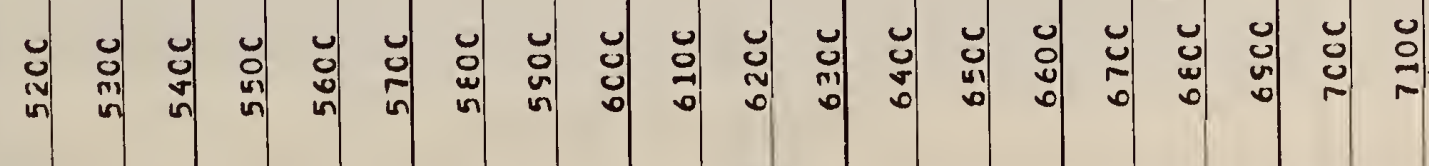




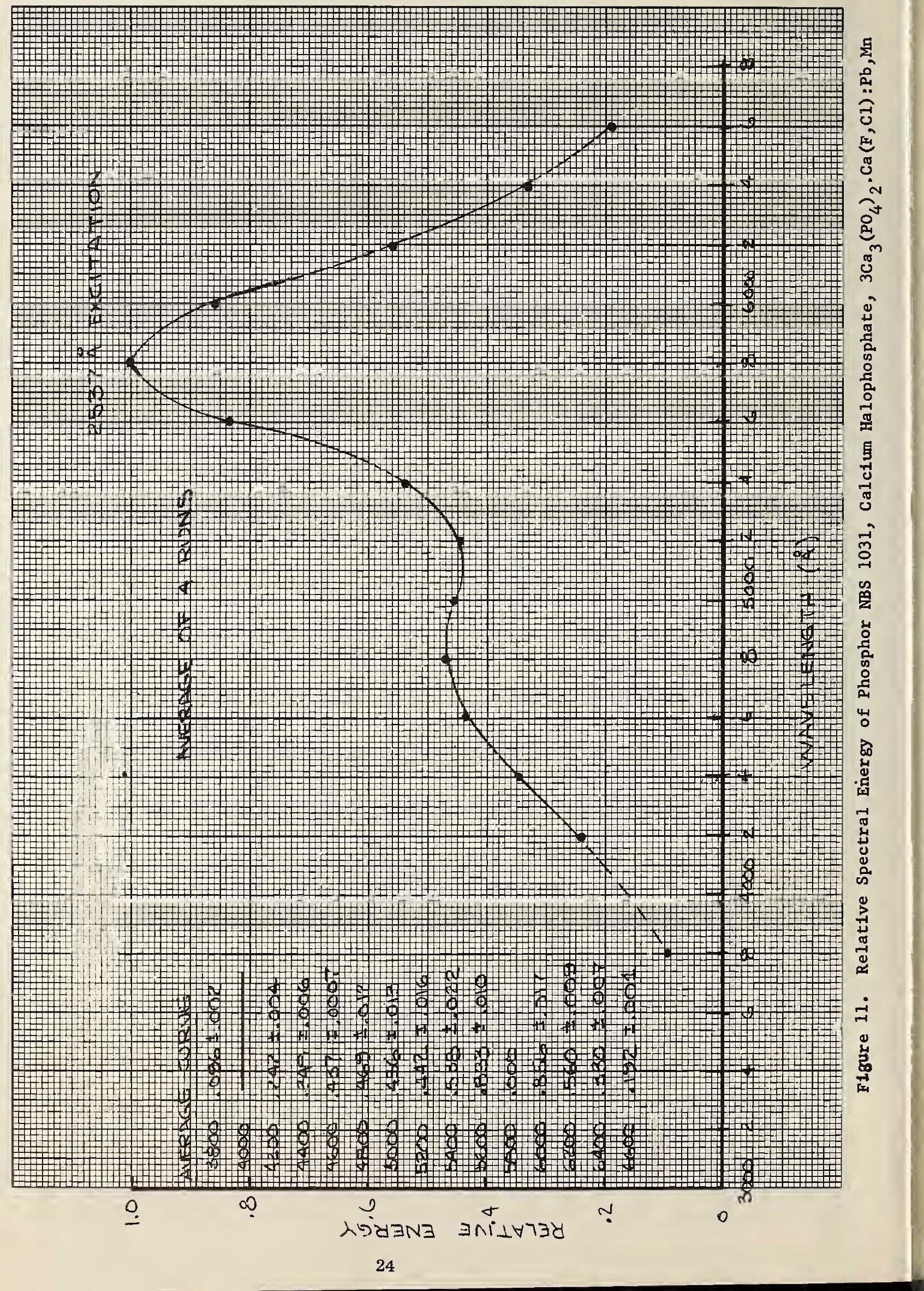




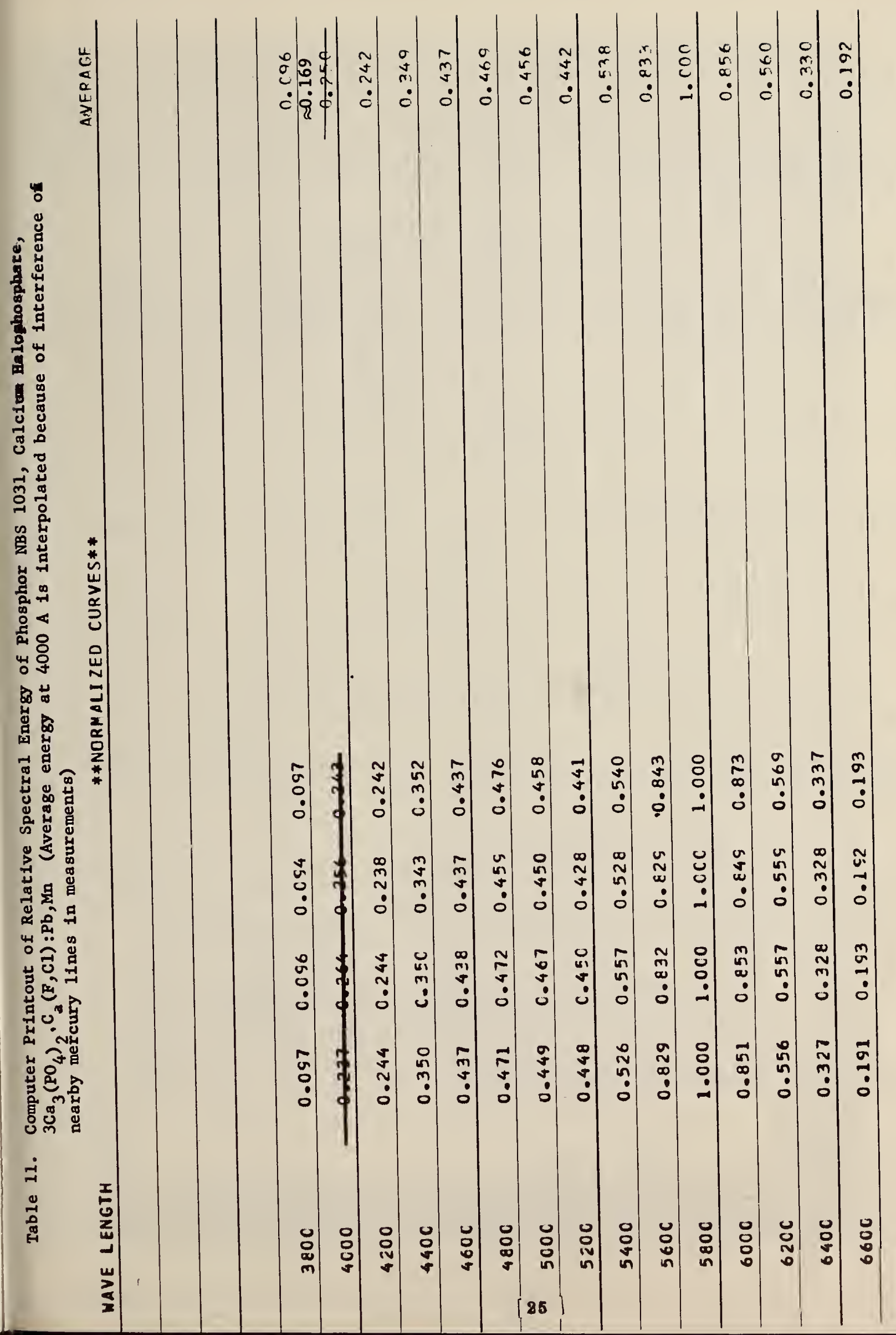


The $45^{\circ}-0^{\circ}$ spectral reflectance factor of the $\mathrm{BaSO}_{4}$ plaque was assumed constant over the wavelength range of interest for each phosphor and the relative spectral emission for a blackbody at $2854^{\circ} \mathrm{K}$ was used for $\mathrm{L}\left(\lambda_{j}\right)$ in a11 calculations involved in correcting the data. The absolute spectra1 reflectance of USP grade (unpublished data) $\mathrm{BaSO}_{4}$ is shown in Figure 12. The $45^{\circ}-0^{\circ}$ spectral reflectance factor of the plaque was assumed to be equal to its spectral reflectance.

\section{Relative Quantum Efficiency}

The relative quantum efficiencies of the 2537 \& excited phosphor samples have been calculated from the scale factors used with a picoammeter during the measurements. The method of calculation is as follows: define

$$
\text { f } \equiv \text { scale factor }
$$

then the calibrated spectral energy distribution is

$$
E(\lambda)=f P(\lambda)
$$

where $P(\lambda)$ is the average curve obtained for each phosphor. Thus, since

$$
E=h v=\frac{h c}{\lambda}
$$

the number of quanta of luminescence is given by,

$$
Q=f \int \frac{P(\lambda)}{\frac{h c}{\lambda}} d \lambda=\frac{f}{h c} \int \lambda P(\lambda) d \lambda .
$$

Since the calculated quantum efficiencies of the samples will be referred to $\mathrm{MgWO}_{4}$, we compute the number of quanta emitted by it as

$$
\mathrm{Q}_{\mathrm{MgWO}_{4}}=\frac{\mathrm{f}_{\mathrm{MgWO}}}{\mathrm{hc}} \int \lambda \mathrm{P}_{\mathrm{MgWO}_{4}}(\lambda) \mathrm{d} \lambda \text {. }
$$

Finally the relative quantum efficiency of each sample is given by,

$$
\epsilon \equiv \operatorname{Relative~Q.E.~}=\frac{\mathrm{Q}}{\mathrm{Q}_{\mathrm{MgWO}_{4}}}=\frac{\mathrm{f} \int \lambda \mathrm{P}(\lambda) \mathrm{d} \lambda}{\mathrm{f}_{\mathrm{MgWO}_{4}} \int \lambda \mathrm{P}(\lambda) \mathrm{d} \lambda}
$$

or for ease of calculation from the data,

$$
\varepsilon=\frac{f_{j=1}^{20} \lambda_{j} P\left(\lambda_{j}\right)}{f_{\mathrm{MgWO}_{4}} \sum_{j=1} \lambda_{j} P\left(\lambda_{j}\right)}
$$






\begin{tabular}{|c|c|c|c|c|c|}
\hline \\
\hline
\end{tabular} 
The following results were obtained with the quantum efficiency of $\mathrm{MgWO}_{4}$ normalized to unity.

RELATIVE QUANTUM EFFICIENCIES

OF $2537 \AA$ EXCITED SAMPLES

Sample No.

1021

1026

$1027\left(\mathrm{M}_{\mathrm{g}} \mathrm{WO}_{4}\right)$

1028

1029

1031

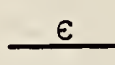

.66

.86

1.00

.86

.85

.82 $\underline{\text { Per Bril (Ref 1) }}$

.83

.89

1.00

.81

.81

.84 
1. A. Bril and W. Hoekstra, "Efficiencies of Phosphors for Short-Wave U1traViolet Excitation," Philip Res. Repts. 16, 356-370, (1961).

2. A. Bril, "Absolute Efficiencies of Phosphors with U1tra-Violet and Cathode-Ray Excitation," Kallman and Sprunch, Luminescence of Organics and Inorganic Materials, Wiley, 1962.

3. "Opitcal Characteristics of Cathode Ray Tube Screens," JEDEC Publication No. 16A, JEDEC Electron Tube Council, January 1966.

4. F. J. Studer, "Measurement of Quantum Efficiency" General Electric Research Laboratory Memo Report, November P-207, November 1959.

5. Dixon and Massey, "Introduction to Statistical Analysis", McGraw-Hi11, 1957 (page 408).

6. Goebe1, Caldwe11, and Hammond, Journal of the Optical Society of America $\underline{56}, 783-788,(1966)$. 


\section{NBS TECHNICAL PUBLICATIONS}

\section{PERIODICALS}

JOURNAL OF RESEARCH reports National Bureau of Standards research and development in physics, mathematics, chemistry, and engineering. Comprehensive scientific papers give complete details of the work, including laboratory data, experimental procedures, and theoretical and mathematical analyses. Illustrated with photographs, drawings, and charts.

Published in three sections, available separately.

\section{- Physics and Chemistry}

Papers of interest primarily to scientists working in these fields. This section covers a broad range of physical and chemical research, with major emphasis on standards of physical measurement, fundamental constants, and properties of matter. Issued six times a year. Annual subscription: Domestic, $\$ 5.00$; foreign, $\$ 6.00^{*}$.

\section{Mathematical Sciences}

Studies and compilations designed mainly for the inathematician and theoretical physicist. Topics in mathematical statistics, theory of experiment design, numerical analysis, theoretical physics and chemistry, logical design and programming of compüters and computer systems. Short numerical tables. Issued quarterly. Annual subscription: Domestic, $\$ 2.25$; foreign, $\$ 2.75^{*}$.

\section{Engineering and Instrumentation}

Reporting results of interest chiefly to the engineer and the applied scientist. This section includes many of the new developments in instrumentation resulting from the Bureau's work in physical measurement, data processing, and development of test methods. It will also cover some of the work in acoustics, applied mechanics, building research, and cryogenic engineering. Issued quarterly. Annual subscription: Domestic, $\$ 2.75$; foreign, $\$ 3.50^{*}$.

\section{TECHNICAL NEWS BULLETIN}

The best single source of information concerning the Bureau's research, developmental, cooperative and publication activities, this monthly publication is designed for the industry-oriented individual whose daily work involves intimate contact with science and technology-for engineers, chemists, physicists, research managers, product-development managers, and company executives. Annual subscription: Domestic, $\$ 1.50$; foreign, $\$ 2.25^{*}$.

Difference in price 18 due to extra cost of foreign mailing.
NONPERIODICALS

Applied Mathematics Series. tables, manuals, and studies.

Building Science Series. Research results, test methods, and performance criteria of building materials, components, systems, and structures.

Handbooks. Recommended codes of engineering and industrial practice (including safety codes) developed in cooperation with interested industries, professional organizations, and regulatory bodies.

Special Publications. Proceedings of NBS conferences, bibliographies, annual reports, wall charts, pamphlets, etc.

Monographs. Major contributions to the technical literature on various subjects related to the Bureau's scientific and technical activities.

National Standard Reference Data Series. NSRDS provides quantitative data on the physical and chemical properties of materials, compiled from the world's literature and critically evaluated.

Product Standards. Provide requirements for sizes, types, quality and methods for testing various industrial products. These standards are developed cooperatively with interested Government and industry groups and provide the basis for common understanding of product characteristics for both buyers and sellers. Their use is voluntary.

Technical Notes. This series consists of communications and reports (covering both other agency and NBS-sponsored work) of limited or transitory interest.

\section{CLEARINGHOUSE}

The Clearinghouse for Federal Scientific and Technical Information, operated by NBS, supplies unclassified information related to Governmentgenerated science and technology in defense, space, a tomic energy, and other national programs. For further information on Clearinghouse services, write:

Clearinghouse

U.S. Department of Commerce

Springfield, Virginia 22151

Order NBS publications from:

Superintendent of Documents

Government Printing Office

Washington, D.C. 20102 
U.S. DEPARTMENT OF COMMERCE

POSTAGE AND FEES PAID

WASHINGTON, D.C. 20230

U.S. DEPARTMENT OF COMMERCE

OFFICIAL BUSINESS 